\title{
CARACTERÍSTICAS FÍSICO-QUIMMICAS E ANÁLISES POLÍNICAS DE AMOSTRAS DE MÉIS DE Apis mellifera L. 1758 (HYMENOPTERA: APIDAE) DA REGIÃO LITORAL NORTE DO ESTADO DA BAHIA
}

\section{GENI DA SILVA SODRÉ}

Engenheira Agrônoma

Orientador: Prof. Dr. LUÍS CARLOS MARCHINI

\begin{abstract}
Dissertação apresentada à Escola Superior de Agricultura "Luiz de Queiroz", Universidade de São Paulo, para obtenção do Título de Mestre em Ciências, Área de Concentração: Entomologia.
\end{abstract}

PIRACICABA

Estado de São Paulo - Brasil

Dezembro - 2000 


\title{
Dados Internacionais de Catalogação na Publicação (CIP) \\ DIVISÃO DE BIBLIOTECA E DOCUMENTAÇÃO - Campus "Luiz de Queiroz"/USP
}

\author{
Sodré, Geni da Silva \\ Características fisico-químicas e análises polínicas de amostras de méis de Apis \\ mellifera L. 1758 (Hymenoptera: Apidae) da regiāo litoral norte do Estado da Bahia / \\ Geni da Silva Sodré. - - Piracicaba, 2000. \\ 83 p. : il.
}

Dissertação (mestrado) - - Escola Superior de Agricultura Luiz de Queiroz, 2000.

Bibliografia.

1. Abelha-africanizada 2. Análise de alimento 3. Mel 4. Pólen I. Título

CDD 638.12

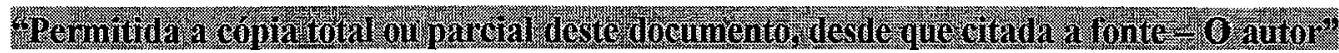


Aos meus pais, Raimunda e

Luiz (in memória), que com amor, carinho e dedicação, sempre me apoiaram em todas as etapas de minha vida,

\title{
DEDICO
}

\author{
Aos meus irmãos \\ Paulo, Lúcia, Rita, \\ Antônio e Edvaldo.
}

OFEREÇO 


\section{AGRADECIMENTOS}

Meus sinceros agradecimentos a todas as pessoas e instituições que, de forma direta ou indireta, contribuíram para a consecução deste trabalho. Em especial:

Ao Prof. Dr. Luís Carlos Marchini pela orientação, amizade, confiança e principalmente apoio concedido em todos os momentos;

À Escola Superior de Agricultura "Luiz de Queiroz" ESALQ/USP, pelo apoio concedido por meio de sua estrutura, em especial ao Setor de Entomologia pela oportunidade e acolhida para a realização deste trabalho;

Aos professores do curso de pós-graduação em Entomologia, pelos ensinamentos transmitidos;

À Dra. Augusta Carolina de C. C. Moreti pela amizade, atenção constante e análise polínica;

Ao Prof. Dr. Sinval Silveira Neto, pela grande ajuda, sugestão e orientação prestada;

Ao professor Dr. Evoneo Berti Filho pelo auxílio na elaboração do "summary";

À Dra Marinéia de Lara Haddad pela orientação nas análises estatísticas;

Ao Prof. Dr. Carlos Alfredo Lopes de Carvalho pela amizade e colaboração desde o início do curso;

Ao.Prof. Oton Meira Marques pelo incentivo;

À Jeane Cruz Portela por todo o seu apoio;

A todos os companheiros do Laboratório de Insetos Úteis pela colaboração e amizade;

Aos colegas, amigos e funcionários do Setor de Entomologia, pelo convívio, amizade, apoio e simpatia. Em especial ao Marcos e Marilene pelos auxílios e sugestões, Ranyse pelo seu auxílio na utilização do programa de análises estatísticas e Elizabeth pela amizade; 
Às bibliotecárias da ESALQ pela colaboração nas pesquisas e elaboração das referências bibliográficas;

Ao laboratorista Luís Lucatti do Departamento de Ciência Biológica, Laboratório de Bioquímica pela ajuda;

Aos apicultores da região litoral norte do Estado da Bahia, pela valiosa colaboração nas coletas das amostras de méis;

À Coordenação de Aperfeiçoamento de Pessoal de Nível Superior (CAPES), pela concessão da bolsa de estudo;

A todos os anjos que acompanham meu caminho. 


\section{SUMÁRIO}

Página

RESUMO................................................................................. vii

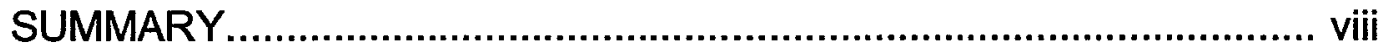

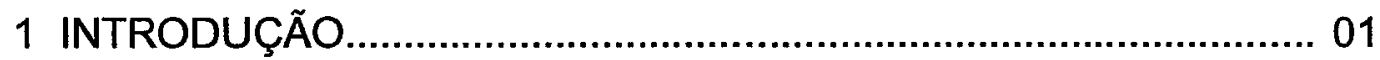

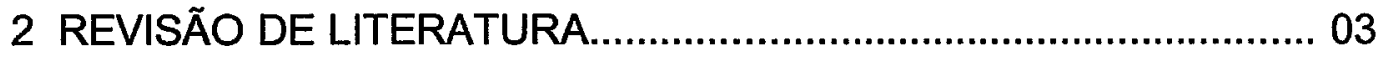

2.1 Análises físico-químicas.......................................................... 03

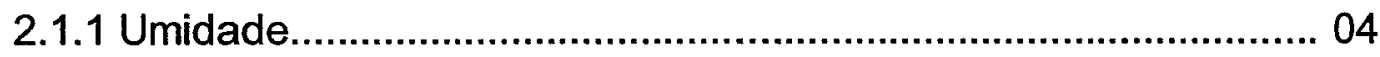

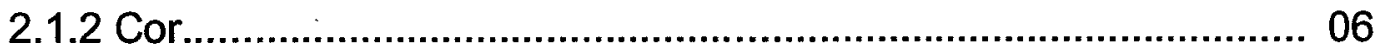

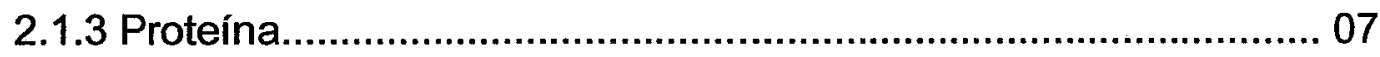

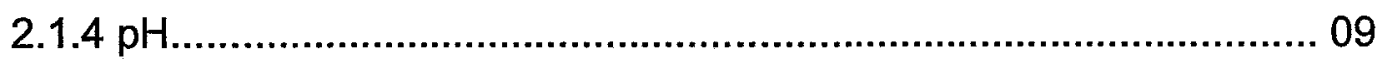

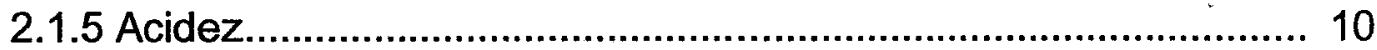

2.1.6 Índice de formol........................................................................ 12

2.1.7 Número de diastase............................................................. 13

2.1.8 Hidroximetilfurfural................................................................... 15

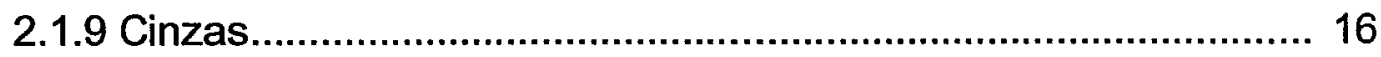

2.1.10 Condutividade elétrica......................................................... 18

2.1.11 Açúcares totais, açúcares redutores e sacarose....................... 20

2.2 Análises polínicas....................................................................... 23

3 MATERIAL E MÉTODOS.......................................................... 26

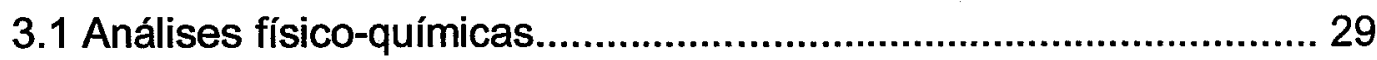

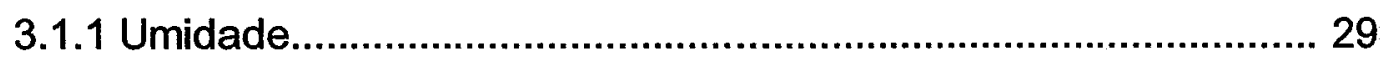

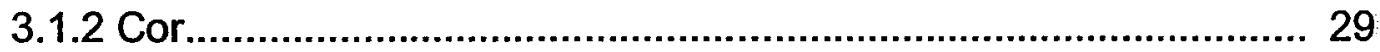

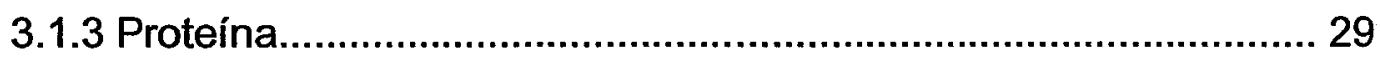

$3.4 \mathrm{pH}$, Acidez e índice de formol................................................ 29

3.1.5 Número de diastase.................................................................. 30

3.1.6 Hidroximetilfurfural........................................................... 30 


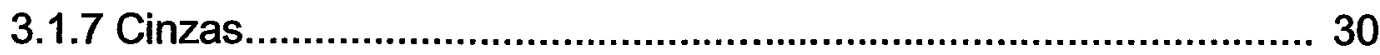

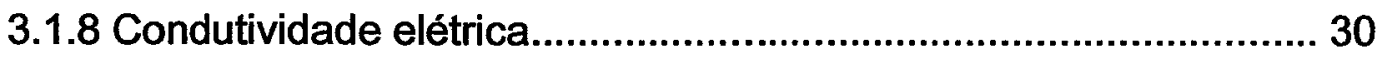

3.1.9 Açúcares totais, açúcares redutores e sacarose........................ 30

3.2 Análises polínicas................................................................... 31

3.2.1 Método qualitativo..................................................................... 31

3.2.2 Método quantitativo.................................................................... 31

3.3 Análise dos dados..................................................................... 31

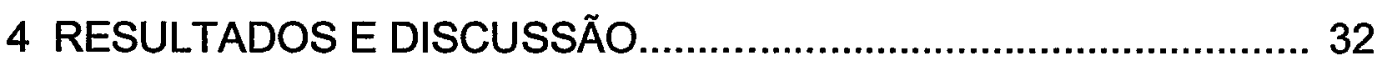

4.1 Análises físico-químicas......................................................... 32

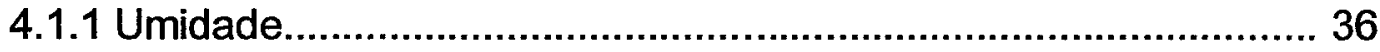

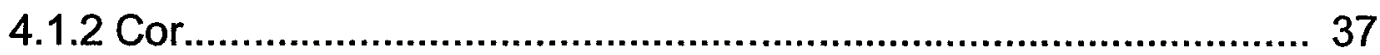

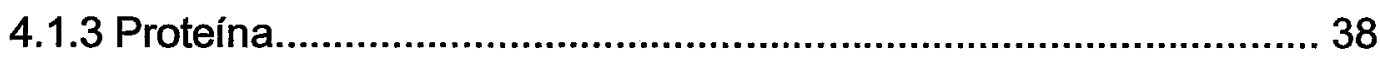

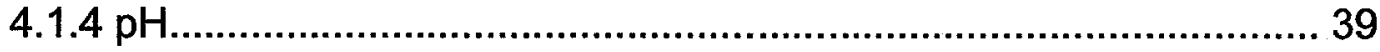

4.1.5 Acidez...................................................................... 41

4.1.6 Índice de formol................................................................ 42

4.1.7 Número de diastase ............................................................. 43

4.1.8 Hidroximetilfurfural.................................................................. 44

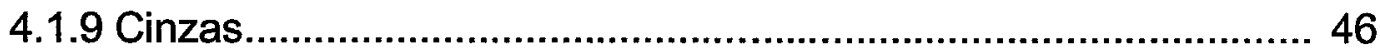

4.1.10 Condutividade elétrica......................................................... 47

4.1.11 Açúcares totais....................................................................... 48

4.1.12 Açúcares redutores............................................................... 48

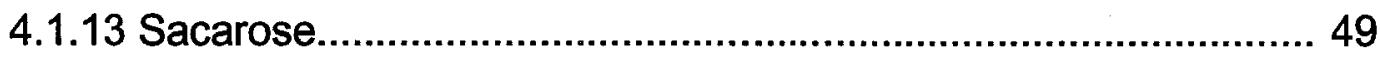

4.2 Análise de agrupamento......................................................... 51

4.3 Análises polínicas.................................................................... 57

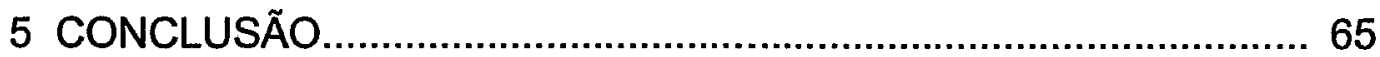

REFERÊNCIAS BIBLIOGRÁFICAS........................................... 66 


\title{
CARACTERÍSTICAS FÍSICO-QUIIMICAS E ANÁLISES POLÍNICAS DE AMOSTRAS DE MÉIS DE Apis mellifera L. 1758 (HYMENOPTERA: APIDAE) DA REGIÃO LITORAL NORTE DO ESTADO DA BAHIA
}

\author{
Autora: GENI DA SILVA SODRÉ \\ Orientador: Prof. Dr. LUÍS CARLOS MARCHINI
}

\section{RESUMO}

Com o objetivo de determinar as características físico-químicas e a origem floral de méis produzidos por Apis mellifera L., 1758, foram determinadas no Laboratório de Insetos Úteis do Setor de Entomologia da Escola Superior de Agricultura "Luz de Queiroz", USP a umidade, cor, proteína, $\mathrm{pH}$, acidez, índice de formol, condutividade elétrica, cinzas, número de diastase, hidroximetilfurfural, açúcares totais, açúcares redutores, sacarose e análises polínicas de 36 amostras de méis colhidas na região litoral norte do Estado da Bahia, entre 01/1999 a 06/2000. Os resultados demonstraram que os valores médios para cada parâmetro físico-químicos das amostras analisadas encontram-se dentro da legislação vigente. Pelas análises polínicas dos méis foram encontrados 27 tipos polínicos, sendo considerados como espécies vegetais dominantes: Eucalyptus sp. (Myrtaceae) (38\%), Mimosa scabrella Benth (Mimosaceae) (28\%), M. verrucata Benth (Mimosaceae) (19\%), tipo Arecaceae $(3,1 \%)$, Citrus sp. (Rutaceae) $(3,1 \%)$, tipo Lithrea (Anacardiaceae) $(3,1 \%)$, tipo Cardia (Boraginaceae) $(3,1 \%)$ e Psidium sp. (Myrtaceae) $(3,1 \%)$. 


\title{
HONEY PHYSICO-CHEMICAL CHARACTERISTICS AND POLLEN \\ SPECTRUM ANALYSIS - Apis mellifera L. 1758 - (HYMENOPTERA: \\ APIDAE) THE NORTHERN COAST OF BAHIA STATE
}

\author{
Author: GENI DA SILVA SODRÉ \\ Adviser: Prof. Dr. LUISS CARLOS MARCHINI
}

\section{SUMMARY}

This paper deals with the physico-chemical characteristics and the floral origin of honey produced by Apis mellifera L., 1758. The humidity, color, protein, $\mathrm{pH}$, formol index, electrical conductivity, ash, number of diastases, hydroxymethylfurfural, total sugars, reducing sugars, sucrose, and pollen analysis of 36 honey samples collected in the northern coast of Bahia state (Jan/1999 to Jun/2000) were determined in the laboratory of Beneficial Insects at the ESALQ (Escola Superior de Agricultura "Luiz de Queiroz"), USP. The results showed that the mean values for each physico-chemical parameter are in agreement with the present legislation. Through the pollen analyses, twentyseven types of pollen were found and the following plant species were considered as dominant: Eucalyptus sp. (Myrtaceae) (38\%), Mimosa scabrella Benth (Mimosaceae) (28\%), M. verrucata Benth (Mimosaceae) (19\%), Arecaceae type (3.1\%), Citrus sp. (Rutaceae) (3.1\%), Lithrea type (Anacardiaceae) (3.1\%), Cardia type (Boraginaceae) (3.1\%), and Psidium sp. (Myrtaceae) (3.1\%). 


\section{INTRODUÇÃO}

O mel é uma substância natural, elaborada pelas abelhas a partir do néctar das flores ou de exsudações sacarínicas de outras partes vivas das plantas, que são coletadas e transformadas através da evaporação da água e da adição de enzimas (Horn et al., 1996). É um alimento apreciado por seu sabor característico e seu considerável valor nutritivo.

Segundo Trevisan et al. (1981) o mel é um alimento importante para o homem, por ser de fácil digestão e assimilação, constituindo-se numa fonte de energia que contribui para o equilibrio do processo biológico do corpo humano, principalmente por conter, em proporções adequadas, fermentos, vitaminas, ácidos, aminoácidos, substâncias bactericidas e aromáticas. Além do seu valor nutritivo, o mel apresenta funções diuréticas ou terapêuticas sendo largamente utilizado na indústria de cosméticos. Esse efeito terapêutico está relacionado com o princípio ativo das plantas visitadas.

Atualmente são encontrados no mercado méis de diferentes origens florais, tais como de eucalipto, laranjeira, silvestres e méis de origens não florais como o mel de exsudato de cana-de-açúcar.

É conveniente ressaltar que o mel é um produto biológico muito complexo, cuja composição varia notavelmente dependendo da flora visitada e das condições climáticas e edafológicas da região onde foi produzido. Esta grande diversidade constitui numa grande dificuldade para o controle de qualidade do mel, já que se trata de um produto natural.

As características físico-químicas e polínicas do mel ainda são pouco conhecidas, principalmente nas regiões tropicais onde existe elevada 
diversidade de flora apícola ássociada às taxas elevadas de umidade e temperatura. Nas regiões brasileiras existem uma grande variação da flora apícola, tornando-se necessária uma caracterização e criação de padrões do mel levando em consideração as diferenças regionais. No Estado da Bahia, apesar da sua diversidade floral e do potencial para exploração apícola, existem poucas informações sobre as características físico-químicas do mel, assim como as plantas importantes para a sua produção.

É de fundamental importância a caracterização de méis visando a criação de padrões, segundo os fatores edafo-climáticos e florísticos da região, estabelecendo critérios comparativos nas análises, e controlando possíveis fraudes desse produto (Crane, 1990).

Assim, a presente pesquisa teve como objetivo determinar as características físico-químicas, a origem floral e as porcentagens de méis que se enquadram nas especificações da legislação brasileira de amostras de méis de Apis mellifera L., 1758, provenientes do litoral norte do Estado da Bahia. 


\section{REVISÃO DE LITERATURA}

\subsection{Análises físico-químicas}

A utilização dos métodos físico-químicos em trabalhos científicos visando a análise de mel, para fins de caracterização, tornou-se de grande importância nos últimos anos. Os estudos sobre méis vêm sendo desenvolvidos em vários países, destacando-se: Arábia Saudita (Mesallan \& El-Shaarawy, 1987; Al-Khalifa \& Al-Arify, 1999), Argentina (Archenti \& Dasso, 1983; Baldi Coronel et al., 1993; Uñates et al.,1999), Brasil (Flechtmann et al., 1963; Vidal \& Fregosi, 1984; Komatsu, 1996; Marchini et al. 1996, 1998; Campos, 1998; Komatsu \& Marchini, 1996, 1998; Azeredo \& Azeredo, 1999; Costa et al., 1999; Carvalho et al., 1998, 2000), Canadá (Sporns et al.,1992; Gonzales et al., 1999), Egito (El-Sherbiny et al., 1980), Espanha (Fernandez-Salguero \& Gomez, 1992; Sancho et al., 1991, 1992), Grécia (Thrasyvoulou,1986; Thrasyvoulou et al.,1995), Itália (Butta et al., 1983; Spettoli, et al.,1983), Uruguai (Rendón, 1996) dentre outros.

Nos trabalhos de análises de méis os pesquisadores comparam os resultados obtidos pelos diferentes métodos com valores pré-estabelecidos (índices de qualidade), os quais são determinados por órgãos oficiais internacionais ou pelo próprio país. Assim, buscam manter a qualidade do mel produzido, como também a fiscalização do mel importado, evitando a entrada de produto adulterado. 


\subsubsection{Umidade}

O conteúdo de água no mel é sem dúvida uma das características mais importantes, por influenciar na sua viscosidade, peso específico, maturidade, cristalização e sabor, condicionando a sua conservação e palatabilidade (Seemann \& Neira, 1988).

Certos microorganismos osmofílicos (tolerantes ao açúcar) quando presentes no mel, multiplicam-se com o aumento da umidade, favorecendo o processo de fermentação. Estes microorganismos estão presentes nos corpos das abelhas, no néctar, no solo, nas áreas de extração e armazenamento do mel (White Júnior 1978).

A umidade no mel é o segundo constituinte em quantidade, variando entre 15 e $20 \%$ do conteúdo total dependendo do clima, origem floral e colheita antes da completa desidratação.

Natarajan \& Yesuvadian (1978) observaram que mais da metade dos méis produzidos em Kerala e Tamitnadu (Índia) continham no mínimo 23\% de umidade e que é comum na India encontrar méis com alto teor de umidade. Phadke (1967) determinou que os méis indianos e importados que possuíam maior quantidade de água e maior acidez mostraram baixo teor de frutose e levulose/frutose.

Temiz (1983) encontrou na Turquia valores de umidade variando de 14,09 a 16,26\% em 10 méis de flor de lavanda, 10 de citrus, 10 de algodão, 10 de Pinus sp., e 7 multiflorais.

Lower (1987) analisando a umidade de méis provenientes de diferentes países como: Brasil, Inglaterra, França, Índia, Japão, Paquistão, Polônia, Romênia, África do Sul, Suécia, Uruguai, encontrou os valores de: $17,60 \% ; 17,00 \% ; 20,64 \% ; 14,17-26,67 \%$; $17,23 \% ; 14,30-28,60 \%$; $21,00 \%$; $16,46 \% ; 16,00 \% ; 18,50 \% ; 17,29 \%$, respectivamente.

Moraes et al. (1989) observaram que a umidade relativa em algumas regiões do Brasil pode ser superior a $90 \%$ e o conteúdo de água no 
mel, em células operculadas, pode ser superior a $23 \%$. Esses autores, reduziram com sucesso tal valor de umidade em 3-4\% mantendo numa sala o mel a $40 \%$ de umidade relativa.

Vit et al. (1994) trabalharam com amostras de méis comercializados na Venezuela e constataram umidade variando de 16 a $20 \%$ para as amostras não adulterados.

Bastos \& Silva (1994) obtiveram na região de Bragança Paulista (SP) os valores de 16 a $18 \%$ de umidade para méis de Apis mellifera e de $21 \%$ para méis de Tetragonisca angustula (jataí).

Na legislação brasileira, a taxa máxima permitida para a umidade é $20 \%$. Em trabalhos sobre umidade de méis brasileiros Flechtmann et al. (1963) encontraram 17,6\%; Pamplona (1989) observou 17,9\%; Stonoga \& Freitas (1991) encontraram 17,9\%; Cortopassi-Laurino \& Gelli (1991) encontraram 19,2\%; Komatsu (1996) verificou variações de 16,4 a 23,4\% e Costa et al. (1999) constataram valores variando de 14,7 a $23 \%$.

Abdelnur et al. (1998) constataram alterações na qualidade de méis de flores de laranjeira, silvestre e de eucalipto, influenciadas pelo tempo e tipo de embalagem em que foram armazenados.

Azeredo et al. (1999) estudaram as características de méis armazenados em diferentes recipientes e temperatura ambiente variando de 26 a $27^{\circ} \mathrm{C}$. Constataram que as amostras armazenadas por um ano apresentaram uma redução de apenas $0,1 \%$ na umidade, e que os valores obtidos encontravam-se abaixo de $20 \%$.

Uñates et al. (1999) em méis de San Luis (Argentina) encontraram valores que estão de acordo com as normas internacionais (21\%) e normas da Argentina (18\%). 


\subsubsection{Cor}

A cor do mel é uma característica sensorial, que pode variar desde o branco água até o âmbar escuro. Este parâmetro está relacionado com a sua origem floral, podendo ser influenciado pelo processamento e armazenamento.

Por ser um produto natural, a cor de um mel novo, extraído da mesma flora apícola, varia de acordo com fatores climáticos durante o fluxo do néctar e a temperatura na qual o mel amadurecerá na colméia (Seemann \& Neira 1988).

Schade et al. (1958) relataram que a proporção de frutose, glicose, conteúdo de nitrogênio e aminoácidos livres têm sido citados como possíveis fatores que determinam a velocidade de escurecimento do mel.

Campos (1998) mencionou que o escurecimento do mel está relacionado com a reação de substâncias polifenólicas com sais de ferro e também com a instabilidade da frutose em solução ácida.

Bath \& Singh (1999) descreveram que a cor escura no mel é um indicador da presença de alto conteúdo de minerais.

Escobar-Martínez et al. (1992) em trabalho de caracterização do mel no Paraguai encontraram uma predominância da cor âmbar claro.

Baldi Coronel et al. (1993) trabalharam com méis da província de Entre Ríos (Argentina), dividindo-a em quatro zonas de acordo com a flora apícola existente e observaram uma forte predominância da coloração âmbar claro e âmbar extra claro, e em duas zonas uma maior variação de cores.

Gomez et al. (1993) encontraram como média a cor branco água em 25 amostras de méis comercializados na Espanha.

Campos (1998) em amostras de méis misturados (mel de melato e mel floral) constatou que com o aumento do teor de melato na mistura, diminui a luminosidade, aumenta ligeiramente a cor vermelha e diminui sensivelmente a cor amarela, tornando-se o produto mais escuro. Nas amostras analisadas, 0 
mel classificado como mel de melato apresentou maior coloração amarela se comparado com o mel floral.

Carvalho et al. (1998) em 15 amostras de méis da Bahia provenientes dos municípios de Cruz das Almas (07), Floresta Azul (01), Itaparica (01), Rio Real (03), Santo Antônio de Jesus (01) e Sapeaçu (02) constataram uma variação de cor âmbar escuro a âmbar extra claro $(60 \%$ âmbar, $20 \%$ âmbar escuro, 13,33\% âmbar claro, 6,67\% âmbar extra claro, respectivamente).

Azeredo et al. (1999) em méis de São Fidélis (Rio de Janeiro) armazenados em diferentes tipos de recipientes, à temperatura de 26 a $27^{\circ} \mathrm{C}$, constataram que, em intervalos regulares de 90 dias não houve variação com relação a cor entre as amostras.

Uñates et al. (1999) em méis de San Luis (Argentina) encontraram predominância das cores âmbar claro e âmbar, seguida da cor âmbar extra claro.

Carvalho et al. (2000) trabalharam com amostras de méis do Recôncavo da Bahia, onde encontraram variações da cor âmbar escuro a branco água (33,33\% âmbar, $16.67 \%$ âmbar escuro, $41,67 \%$ âmbar claro, $5,56 \%$ âmbar extra claro, $2,78 \%$ branco água).

\subsubsection{Proteína}

A proteína é um dos constituintes no mel que influencia em muitas de suas propriedades, apesar de estar presente em pequenas e variáveis quantidades (Komatsu, 1996).

Dentre os aminoácido encontrados no mel, a prolina é o que está presente em maior quantidade, representando cerca de $50-85 \%$ do total (White Júnior, 1978). 
White Júnior \& Rudyj (1978) observaram variações de 0,2 a 0,99\% para o teor de proteínas em amostras de méis dos Estados Unidos.

Archenti (1984) encontrou uma média de 0,18\% para proteína total dos méis obtidos em Chubut (Argentina).

Imperatriz-Fonseca et al. (1987) estudando amostras de méis da regiões norte, nordeste e sul do Brasil, encontraram um conteúdo médio de proteína igual a 1,58\% para mel de flores de Citrus e 1,92-2,76\% para mel de flores de Eucalyptus.

Escobar-Martínez et al. (1992) pretendendo estabelecer um padrão de qualidade para mel, dividiram o Paraguai em 5 zonas melíferas, onde realizaram um estudo sobre a composição físico-química, biológica e organoléptica de amostras representativas do país. Para a proteína bruta o valor médio encontrado foi de $1,63 \%$.

Baldi Coronel et al. (1993) observaram variações de 0,05 e 0,2\% de proteínas em méis de Entre Ríos (Argentina).

Peng \& Pan (1994) analisaram a proteína de méis de flores de Ziziphus jujuba, Astragalus sinicus, Sesame sp. e de algodão, na China, encontrando variações entre 0,048 e $0,42 \%$.

Komatsu (1996) avaliou 96 amostras de méis silvestres de diferentes regiões do Estado de São Paulo, obteve valores que variaram de 0,0 a $1,6 \%$ de proteína.

Bath \& Singh (1999) encontraram para proteínas os valores de 0,036 e $0,6 \%$, em méis de Helianthus annuus e Eucalyptus lanceolatus, respectivamente. 


\subsubsection{PH}

$\mathrm{O} \mathrm{pH}$ determinado nas análises de mel refere-se aos íons hidrogênio presentes na sua solução (Vidal \& Fregosi, 1984). Todos os méis são ácidos, e o $\mathrm{pH}$ (inferior a 4,0 para méis de origem floral e superior a 4,5 para mel de melato) é influenciado pela sua origem botânica (Frías \& Hardisson, 1992). Os méis brasileiros de Apis têm o valor de $\mathrm{pH}$ variando de 3,95 a 4,09 e os de meliponíneos de 3,39 a 4,63 (Cortopassi-Laurino \& Gelli, 1991).

Seemann \& Neira (1988) relataram que o valor do pH no mel é afetado pela concentração de diferentes ácidos e pelo cálcio, sódio, potássio e outros constituintes das cinzas.

Segundo Vidal \& Fregosi (1984), além da temperatura, o pH do mel tem importância para a velocidade de formação do hidroximetilfurfural (HMF).

O Estado de São Paulo dispõe de uma variável flora apícola que influencia a qualidade do mel. Flechtmann et al. (1963) encontraram em 17 amostras de méis de flores de eucalipto, laranjeira e de outras espécies melíferas do município de Suzano, Pindamonhangaba, Guaratinguetá, Agudos, Bebedouro, Urupês e Aguaí o valor médio de pH 4,4. Enquanto Komatsu (1996) encontrou uma média de 3,4 para méis de 94 municípios do Estado.

Faraji-Haremi \& Hosseini (1987) analisaram méis iranianos e encontraram valor médio de $\mathrm{pH}$ igual a 3,91, com intervalo de variação de 3,5 a 4,3 .

Fernandez-Salguero \& Gomez (1992) determinaram o pH de 38 alimentos na Espanha mostrando que o mel foi o produto que apresentou 0 menor valor com uma faixa de 4,08-6,72. Crecente \& Latorre (1993) também trabalharam com méis da Espanha onde encontraram para o $\mathrm{pH}$ valores entre 3,46 e 4,77. Gomez et al. (1993) encontraram em méis de eucaliptos (Eucalyptus sp.) o pH com uma média de 3,9. 
Baldi Coronel et al. (1993) determinaram que os valores do $\mathrm{pH}$ de méis de Entre Ríos (Argentina) variaram entre 3 e 5.

Bastos \& Silva (1994) encontraram pH variando de 3,26 a 4,12, para amostras de méis de Apis mellifera e $\mathrm{pH}$ de 3,66 para amostras de méis de Tetragonisca angustula.

Horn et al. (1996) analisaram méis de diferentes regiões brasileiras e encontraram a média do $\mathrm{pH}$ de 3,8 por região e por estado 3,9, embora tenham observado na região sul (Estado do Rio Grande do Sul) uma amostra atípica com valor de $\mathrm{pH} 5,7$.

Thrasyvoulou \& Manikis (1995) encontraram valores para o $\mathrm{pH}$ entre 5,9 e 3,3 em méis uniflorais da Grécia.

Andrade et al. (1999) verificaram que os méis de Portugal apresentaram valores de $\mathrm{pH}$ entre 3,6 a 4,46 .

\subsubsection{Acidez}

A acidez é um importante critério de qualidade por contribuir para a estabilidade do mel frente ao desenvolvimento de microrganismos. São encontrados no mel: ácido fórmico, acético, benzóico, butírico, cítrico, isovalérico, láctico, maléico, málico, oxálico, fenilacético, propiônico, piroglutânico, succínico, valérico e glicônico (Seemann \& Neira,1988). Os ácidos dos méis estão dissolvidos na solução aquosa e produzem íons de hidrogênio que promovem a sua acidez ativa. $O$ valor dessa acidez permite detectar o processo de fermentação comum em méis.

Horn et al. (1996) descreveram que dentre os ácidos encontrados nos méis, o mais comum é o glucônico que é produzido pela ação da enzima glicose oxidase sobre a glicose. Conforme Frías \& Hardisson (1992), a ação de transformação é lenta em méis mais densos, porém, mais rápida em méis fluidos. É influenciada também, pela quantidade de ácido obtida no tempo que 
transcorre entre a coleta do néctar e o máximo do volume do néctar que é depositado nos favos. Segundo Brasil (1997), a acidez máxima permitida para o $\mathrm{mel} \mathrm{e}$ de $40 \mathrm{meq} / \mathrm{kg}$.

Com a finalidade de verificar se os méis comercializados em Milão (Itália) correspondiam ao padrão em vigor, Butta et al. (1983) determinaram alguns parâmetros em 35 amostras nacionais e estrangeiras de diferentes floradas. Constataram que a acidez de 4 méis ( $11 \%$ das amostras) apresentou valores maiores que $40 \mathrm{meq} / \mathrm{kg}$ e valor médio de $25,60 \mathrm{meq} / \mathrm{kg}$.

Cornejo (1988), em um breve relato, descreveu que a acidez também dá indicações sobre as condições de armazenamento e fermentação do mel. Segundo o autor, o mel de boa qualidade deveria ter um conteúdo médio normal de $10 \mathrm{meq} / \mathrm{kg}$.

$\mathrm{Na}$ província de Zaragosa (Espanha), Peréz et al. (1990) estudaram 27 amostras de méis monoflorais e encontraram como valor médio para a acidez de 19,45 meq/kg. Sancho et al. (1991) analisaram a acidez de amostras de méis do norte da Espanha, das províncias Vizcaya, Alava e Guipúzcoa e encontraram, respectivamente 26,$1 ; 25,9$ e 23,8meq/kg.

Rendón (1996) comparou a composição físico-química de méis importados da Austrália, Argentina, Cuba, China, URSS com os nacionais da Espanha. Constatou que os méis importados possuiam uma acidez mais elevada $(32,74-46,66 \mathrm{meq} / \mathrm{kg})$ do que os méis espanhóis $(27,37 \mathrm{meq} / \mathrm{kg})$.

Carvalho et al. (1998) determinaram parâmetros físico-químicos de amostras de méis de Apis mellifera L. produzidos no Estado da Bahia onde encontraram o valor de 16,36 meq/kg para a acidez. Costa et al. (1999) trabalharam com amostras de méis de diferentes origens florais e de diversas regiões do Brasil observando valores de 8,20 a 50,0 meq/kg.

Mendes et al. (1998) e Andrade et al. (1999) determinaram valores de acidez dentro do limite estabelecido $(40 \mathrm{meq} / \mathrm{Kg})$ em méis portugueses, indicando ausência da fermentação indesejável. 
Uñates et al. (1999) verificaram que os valores de 14,98 a 35,46 para a acidez em méis de San Luis (Argentina), estavam de acordo com as normas nacional e internacional $(40 \mathrm{meq} / \mathrm{kg})$.

\subsection{6 Índice de formol}

O índice de formol é um parâmetro muito importante no mel por representar uma medida global dos compostos aminados, o que permite avaliar o conteúdo em peptídios, proteínas e aminoácidos. Segundo McGregor (1979) existem de 11 a 21 diferentes compostos aminados no mel, sendo a prolina o predominante.

Um valor muito baixo para o índice de formol pode manifestar a adulteração por meio de produtos artificiais, enquanto excessivamente alto indica que as abelhas foram alimentadas com hidrolizado de proteínas (Simal \& Huidobro,1984). Frías \& Hardisson (1992) relataram que diversos autores consideram que o índice de formol poderia ser utilizado para comprovar a autenticidade do mel. Assim, em diversos procedimentos para analisar grupos aminos nesse produto encontraram uma média de $0,0034 \%$ para méis claros e $0,0058 \%$ para méis escuros.

Temiz (1983) estudou na região da Turquia 47 amostras de méis recém-colhidos encontrando uma variação de 4,5 a $8,6 \mathrm{ml} / \mathrm{kg}$ para o índice de formol. Esses intervalos enquadraram-se na faixa aceitável estabelecida para padrão europeu e da Turquia.

Trabalho realizado por Komatsu (1996) com análises físicoquímicas de amostras de méis (de exsudado de cana-de-açúcar, de flores de eucalipto, de flores silvestres e flores de laranjeira) no Estado de São Paulo, encontrou variações de 5,0 a 21, $5 \mathrm{ml} / \mathrm{kg}$ para o índice de formol.

Carvalho et al. (1998) em 15 amostras de méis da Bahia (Cruz das Almas=07; Floresta Azul=01; Itaparica=01; Rio Real=03; Santo Antônio de 
Jesus=01 e Sapeaçu=02), obtiveram para o índice de formol o valor médio de $16,49 \mathrm{ml} / \mathrm{kg}$.

Andrade et al. (1999) encontraram para o índice de formol variações entre 0,45 e 1,55 meq/100g em amostras de méis de Portugal.

\subsubsection{Número de diastase}

A diastase é um nome comum dado à enzima $\alpha$-amilase, que tem por função digerir o amido e está presente em diferentes concentrações no mel (White Júnior, 1992).

As enzimas presentes no mel são provenientes, principalmente, das glândulas hipofaringeanas das abelhas e, em menor proporção dos grãos de pólen nelas contidos (Pamplona, 1989). Segundo Vansell et al. (1929), existe uma perfeita correlação entre a quantidade de pólen presente no mel e a atividade de diastase.

Soloveve (1964) considerou a diastase como um importante critério para avaliar a qualidade do mel, podendo indicar o superaquecimento, o que compromete seriamente o produto; salienta ainda que a baixa atividade da diastase em méis claros não pode servir como índice de adulteração.

Para o número de diastase, aceita-se um mínimo de 8 na escala de Gothe, exceção para aqueles méis com um baixo conteúdo enzimático, como os méis de citros, os quais podem possuir um mínimo de três na mesma escala, sempre que o conteúdo de HMF não exceda a 15mg/kg (Brasil, 1997).

Balenovic et al. (1988), em 44 amostras de méis, encontraram para o número de diastase valores maiores que 8 (escala de Gothe) e HMF menor que $40 \mathrm{mg} / \mathrm{kg}$, observando em ambos os tipos de méis uma correlação entre esses dois parâmetros.

Persano-Oddo et al. (1990) estudaram a presença de enzimas de méis uniflorais italianos de diferentes origens botânicas com o objetivo de 
apresentar a variação no valor da diastase. Concluíram que essa variabilidade se deve, provavelmente, a uma série de fatores extrínsecos e intrínsecos incontroláveis.

White Júnior (1992) descreveu que méis das regiões quentes e secas apresentam menor quantidade de enzimas se comparados com as regiões frias e úmidas.

Bastos \& Silva (1994) encontraram na região de Bragança Paulista (SP) os valores de 10 e 9 (escala de Gothe) para diastase em méis de Apis mellifera e Tetragonisca angustula, respectivamente.

Bonvehí \& Call (1995) analisaram amostras de méis de Citrus sp. produzidos na Espanha onde encontraram uma variação do número de diastase de 10,3 a 20 (escala de Ghote).

Komatsu \& Marchini (1996) determinaram valor médio de 9,4 (escala de Gothe) para o índice de diastase em 34 amostras de méis de flores de laranjeira no Estado de São Paulo.

Komatsu (1996) em seu trabalho de caracterização físico-químicas de méis no Estado de São Paulo encontrou para o índice de diastase dos méis de flores silvestres, eucalipto, laranjeira e exsudato de cana-de-açúcar variações de 5,0 a 38,5 (escala de Gothe).

Conforme Mendes et al. (1998), amostras de méis de Portugal apresentaram variações de 8 a 22 (escala de Gothe) para o número de diastase.

Azeredo et al. (1999) avaliaram amostras de méis de São Fidélis (Rio de Janeiro) armazenadas em diferentes condições e constataram que com o passar do tempo, independentemente do tipo de recipiente e da forma de armazenamento, ocorreu uma diminuição no número de diastase.

Al-Khalifa \& Al-Arify (1999) analisaram amostras de méis da Arábia Saudita obtendo uma variação de 3,3 a 12 (escala de Gothe) para o número de diastase. 


\subsubsection{Hidroximetilfurfural}

O hidroximetilfurfural (HMF) é o produto formado através do aquecimento ou armazenamento do mel. É um parâmetro que além do superaquecimento também pode indicar a idade do mel (Salinas et al., 1991). Conforme Veríssimo (1988), o HMF é um indicador de qualidade no mel, visto que, quando elevado, indica uma queda considerável no seu valor nutritivo, pela destruição através do aquecimento de algumas vitaminas e enzimas que são termolábeis.

White Júnior (1978) cita que o HMF é formado pela reação de certos açúcares com ácidos. O HMF presente no mel pode aumentar com a elevação de temperatura, sendo ainda afetado pela acidez, $\mathrm{pH}$, conteúdo de água e minerais. Seemann \& Neira (1988) relataram que o HMF se forma por decomposição da frutose em presença de ácidos. Segundo esses autores, além do aquecimento e armazenamento, o HMF é formado por adição de açúcar invertido.

Wootton \& Ryall (1975) analisaram amostras de méis comercializados em Milão onde encontraram como valor médio de $37,42 \mathrm{mg} / \mathrm{kg}$ para HMF.

A fim de verificar a adulteração dos méis vendidos na Suíça, Reio \& Englund (1985) analisaram 55 amostras de méis importados de 14 países. Algumas amostras da Bulgária, Romênia, Cuba, Caribe, México e Estados Unidos (Califórnia), tinham HMF na faixa de 6,6 a $95,2 \mathrm{mg} / \mathrm{kg}$, sendo o último valor superior ao permitido pelo "Codex Alimentarius Commission" que é 40 $\mathrm{mg} / \mathrm{kg}$; mostrando assim que o mel tinha sido aquecido ou armazenado por um longo tempo.

Hase \& Aida (1986) verificaram que os méis japoneses, geralmente apresentavam uma concentração de HMF menor que a dos importados. Méis processados tinham valores de HMF mais altos que os não 
processados. Os autores propuseram que os padrões internacionais de conteúdo de HMF fossem alterados de $80 \mathrm{mg} / \mathrm{kg}$ para $49 \mathrm{mg} / \mathrm{kg}$.

Vit (1988), num trabalho para avaliar a extensão das fraudes no comércio de méis da Venezuela, considerou o HMF como um dos parâmetros mais úteis para detectar diferenças entre tipos de méis.

Marchini et al. (1996) analisaram características qualitativas de méis florais (de eucaliptos, silvestre e de laranjeira) que passaram por descristalização (microondas, banho-maria e sol) encontrando os seguintes valores médios de HMF, para flores silvestre: 11,42; 15,36; 15,41; 15,50; flores de laranjeira: 22,08; 23,67; 23,57; 23,81; e flores de eucalipto: 22,66; 24,05; 23,$09 ; 23,28$, respectivamente.

Trabalho realizado por Rendón (1996), na Espanha, determinou os valores médios de $14,8 \mathrm{mg} / \mathrm{kg}$ para o HMF em méis importados e de 2,41 a $6,03 \mathrm{mg} / \mathrm{kg}$ para os nacionais.

Issa et al. (1998) constataram que os méis escuros apresentaram valores maiores de HMF em relação aos méis mais claros. Amostras aquecidas a $65^{\circ} \mathrm{C}$ apresentaram um pequeno aumento de HMF mostrando que a análise de HMF isoladamente não pode ser um indicador de qualidade.

Costa et al. (1999) obtiveram variações para o HMF de 1,70 a 38,0 $\mathrm{mg} / \mathrm{kg}$ com méis de diferentes origens florais.

Bath \& Singh (1999) estudaram a composição de méis florais de Heliantus annuus e Eucalyptus lanceolatus e constataram os seguintes valores médios de HMF: 4,45 mg/100g e 1,23mg/100g, respectivamente.

\subsubsection{Cinzas}

O teor de cinzas é bastante utilizado nas determinações que visam verificar a qualidade do mel e expressa o conteúdo de minerais presentes nele. 
Os sais minerais encontrados no mel podem ser modificados por fatores relativos às abelhas, ao apicultor, clima, solo e flora (Lasceve \& Gonnet, 1974).

Bogdanov (1999) relatou que o conteúdo de cinzas no mel é um critério de qualidade e que está relacionado com a sua origem botânica. $\mathrm{O}$ mel de origem floral tem um menor conteúdo de cinza se comparado com o mel de "honeydew".

Ibrahim et al. (1977) encontraram na constituição química do mel de laranja um baixo conteúdo de cinzas.

Accorti et al. (1986) analisaram 279 amostras de méis de diferentes origem florais e obtiveram uma relação entre o teor de cinzas e a condutividade elétrica através de uma equação de regressão. Os autores sugeriram que a avaliação da condutividade elétrica poderia substituir o conteúdo de cinzas nos métodos analíticos oficiais.

Ortiz (1988) constatou que méis com baixos conteúdos de cinzas tenderam para uma cor amarelo claro, ao passo que méis com conteúdo de cinzas relativamente alto eram mais escuros, e nenhuma correlação foi observada para os valores intermediários.

Olek et al. (1987) estudando a composição do mel coletado no Nepal, produzido por Apis laboriosa (1800m de altitude) e por Apis cerana (1200-1500m de altitude), determinaram um conteúdo de cinzas igual a $0,66 \%$ (A. cerana) e $0,42 \%$ (A. laboriosa).

Bastos \& Silva (1994) ao estudarem o teor de cinzas, encontraram para o mel produzido por Apis mellifera teores variando de $0,95 \%$ a $0,024 \%$, enquanto que para amostra de mel de Tetragonisca angustula teor médio de $0,29 \%$.

Pamplona (1989) em amostras de méis de diferentes origens florais e de várias regiões do Brasil, encontrou diferentes concentrações de minerais para cada tipo de mel produzido por Apis mellifera. A autora fez considerações sobre a influência do tipo de clima de cada região no conteúdo mineral presente no mel. 
Baldi Coronel et al. (1993) constataram para o conteúdo de cinzas valores entre 0,05 a $0,65 \%$ em amostras de méis provenientes da província de Entre Ríos (Argentina).

Rendón (1996) analisando amostras de méis da Espanha, verificou variações de $0,41 \%$ a $0,82 \%$ para o teor de cinzas, sendo que esses valores diferiram de méis estrangeiros que apresentaram teor de $0,27 \%$.

Mendes et al. (1998) trabalharam com amostras de méis portugueses encontrando valores que variaram de 0,1 a $0,5 \%$ para a cinza. Enquanto que Andrade et al. (1999) obtiveram valores entre de 0,04-0,52\%.

Segundo Al-Khalifa \& Al-Arify (1999) todos os méis têm normalmente baixo conteúdo de cinzas, sendo que o material coletado pelas abelhas durante a procura de alimento influencia na sua quantidade. Os autores analisaram amostras de méis da Arábia Saudita e constataram para o conteúdo de cinzas valores abaixo de $0,5 \%$.

Carvalho et al. (2000) trabalharam com amostras de méis da Bahia obtendo para o conteúdo de cinzas valor médio de $0,14 \%$.

\subsubsection{Condutividade elétrica}

A condutividade elétrica é considerada um bom critério de identificação da origem floral do mel. Este parâmetro depende do conteúdo de cinzas e ácidos presentes no mel (Bogdanov, 1999). Aganin (1971) concluiu que a determinação da condutividade elétrica pode ser utilizada como método suplementar de determinação da origem botânica do mel.

Crane (1990) relatou que a condutividade elétrica depende dos ácidos orgânicos e dos sais minerais, além da proteína e outras substâncias.

Stefanini (1984) determinou a condutividade elétrica, entre outras características, de 262 amostras de méis. O autor observou certas correlações, 
que através de regressão linear simples poderiam ser calculadas entre pares de 3 variáveis: condutividade elétrica, cinzas e $\mathrm{pH}$.

Thrasyvoulou \& Manikis (1995) encontraram valores de condutividade elétrica variando de 191 a $1540 \mu \mathrm{S}$ em amostras de méis gregos de diferentes origens florais.

Persano-Oddo et al. (1995) analisaram méis de diferentes origens florais provenientes da Itália e constataram para a condutividade elétrica valores de 90 a $2110 \mu S$.

Horn et al. (1996) em amostras de méis brasileiros não verificaram diferenças significativas nas análises de variância para a condutividade elétrica, embora tenham encontrado valor mínimo de $100 \mu \mathrm{S}$ e máximo de $2103 \mu \mathrm{S}$.

Rendón (1996) observou condutividade elétrica variando de $503 \mu S$ a $993 \mu \mathrm{S}$ para méis produzidos na Espanha.

Campos (1998) relatou que méis de mesma origem floral apresentam condutividade elétrica muito semelhante, mesmo que as origens geográficas e as condições climáticas sejam distintas.

Carvalho et al. (1998) trabalharam com amostras de méis da Bahia provenientes dos municípios de Cruz das Almas (07), Floresta Azul (01), Itaparica (01), Rio Real (03), Santo Antônio de Jesus (01) e Sapeaçu (02), encontrando, para a condutividade elétrica, o valor médio de $444,29 \mu \mathrm{S}$.

Andrade et al. (1999) trabalharam com amostras de méis de Portugal e encontraram uma média de $522 \mu \mathrm{S}$ para a condutividade.

Carvalho et al. (2000) constataram para a condutividade elétrica, valor médio de $591,85 \mu \mathrm{S}$ em amostras de méis provenientes da Bahia. 


\subsubsection{Açúcares totais, açúcares redutores e sacarose}

Os carboidratos são os componentes presentes em maior concentração no mel. Os monossacarídios, frutose e glicose, são as frações dominantes, os quais são encontrados em torno de 85 a $95 \%$ sendo o restante representado por dissacarídios e trissacarídios (White Júnior,1979). O mesmo autor descreveu que os açúcares influenciam na viscosidade, higroscopicidade, granulação e valor energético do mel.

A glicose é um açúcar relativamente insolúvel e a sua quantidade no mel determina a tendência à cristalização. A frutose é responsável pela doçura do mel e a sua alta higroscopicidade faz com que absorva umidade do ar (Horn et al., 1996). A proporção da sacarose presente no mel é em torno de 2 a $3 \%$ e quando este valor for muito alto, indica mel verde ou adulterado.

Na maioria dos tipos de méis predomina a frutose sendo que, em alguns, a quantidade de glicose é superior, como os méis da flor de Brassica napus (Seemann \& Neira, 1988).

Os açúcares redutores (glicose e frutose) são substâncias com capacidade de reduzir fons de cobre em solução alcalina. A sacarose é um açúcar não redutor oligossacarídeo, sendo passivel de hidrólise pela ação de ácidos diluídos ou enzimas (invertase), resultando em dois monossacarídeos, frutose e glicose (Vidal \& Fregosi, 1984).

El-Sherbiny et el. (1980) em análise de méis egípcios de flores de Citrus encontraram como valores médios de $75,3 \%$ e $3,6 \%$ para açúcares redutores e sacarose, respectivamente. Tabio et al. (1987) obtiveram $68 \%$ de açúcares redutores e $2,2 \%$ de sacarose.

Huidobro \& Simal (1984) analisaram 91 amostras de méis da Galícia (Espanha), utilizando a combinação dos métodos redutiométrico, gravimétrico e enzimático, encontrando $62,9 \%$ de açúcares redutores e $11,0 \%$ de sacarose. 
Amaral et al. (1986) em 16 amostras de méis (9 de flores de eucalipto e 7 de flores de laranjeira) produzidas em várias regiões do Estado de São Paulo, obtiveram como resultados os valores médios de $77,6 \%$ para açúcares totais em méis de flores de eucalipto e $74,85 \%$ para méis de flores de laranjeira.

Hankin (1987) analisou 58 amostras de méis norte-americano obtendo em média $37 \%$ de frutose e $31 \%$ de glicose.

Olek et al. (1987) realizaram pesquisa no Nepal sobre a composição química de méis produzidos por Apis cerana, a uma altitude de $1200-1500 \mathrm{~m}$, e para Apis laboriosa a uma altitude de $1800 \mathrm{~m}$. Encontraram os valores médios de $74,26 \%$ e $64,70 \%$ para açúcares redutores e 2,51\% e 3,34\% para sacarose, respectivamente.

Cornejo (1988) observou que açúcares redutores, principalmente glicose e frutose, constituem cerca de $72-73 \%$ do mel, indicando riqueza de hidrato de carbono, responsável pela consistência pegajosa e viscosa.

Martinez et al. (1993) analisaram amostras de méis da Espanha, constatando para açúcares redutores um valor médio de 68,62 e para sacarose o valor médio de $2,02 \%$.

Bastos \& Silva (1994) encontraram variações de $71,42 \%$ a $86,07 \%$ em amostras de méis de Apis mellifera e 65,68\% para Tetragonisca angustula.

Komatsu (1996) estudou o teor de açúcares redutores de méis de flores de laranjeira, eucalipto, silvestre e de exsudato de cana-de-açúcar no Estado de São Paulo e encontrou valores médios de 74,$6 ; 72,3 ; 72,6 ; 68,2$, respectivamente.

Rodrigues et al. (1996) analisaram características qualitativas da parte cristalizada e do sobrenadante de amostras de méis de flores de eucalipto e flores silvestres. Obtiveram para açúcares totais, redutores e sacarose os valores de $73,10 \% ; 47,27$ e $1,11 \%$ (flores de eucalipto), 73,$12 ; 72,67$ e $0,43 \%$ (flores silvestres) na parte sobrenadante. Para a parte cristalizada constataram os seguintes valores de açúcares totais, redutores e sacarose: 76,52; 77,86 e 
$1,27 \%$ ( flores de eucalipto) e 81,$38 ; 79,77$ e $1,53 \%$ (flores silvestres), respectivamente.

Analisando amostras de méis de flores silvestres no Estado de São Paulo, Komatsu \& Marchini (1998) determinaram a concentração média de $72,6 \%$ para os açúcares redutores e para a sacarose valor médio de 2,4 .

Andrade et al. (1999) trabalharam com amostras de méis de Portugal e encontraram valores acima de $65 \%$ para açúcares redutores e valores abaixo de $5 \%$ para sacarose. Os dois parâmetros confirmaram que os méis analisados eram de origem floral.

Costa et al. (1999) analisaram amostras de méis de diferentes regiões do Brasil e encontraram para frutose valores de 27,8 a 47,2 e para glicose valores de 24,0 a $38,7 \%$.

Uñates et al. (1999) em amostras da méis de San Luis (Argentina) encontraram, para açúcares redutores, valores de 66,00 a $80,01 \%$, e para açúcares não redutores valores de 1,83 a $7,50 \%$. 


\subsection{Análises polínicas}

"A análise polínica do mel auxilia no reconhecimento das plantas apícolas utilizadas pelas abelhas para produção de mel e é imprescindível para os apicultores, mostrando fonte adequada e de abundante suprimento de néctar e pólen (Hower, 1953).

Barth (1989) relatou que a abelha, ao coletar o néctar das flores involuntariamente, coleta também o pólen, sendo este regurgitado juntamente com o néctar nos alvéolos melíferos. Desta maneira, o pólen aparecerá no mel constituindo importante indicador de sua origem botânica e geográfica.

Através da análise quantitativa de grãos de pólen, é possível estabelecer a proporção com que cada planta nectarífera contribui para a constituição do mel (lamaw \& Melhem, 1979).

Estudos sobre análise de pólen de méis brasileiros, foram desenvolvidos por Santos (1961, 1964, 1974); Barth ( 1970 a,b,c 1971, 1989, 1990); Cortopassi-Laurino \& Gelli (1991); Bastos (1998); Marchini et al. (1997); Moreti et al. (1998, 2000); Carvalho et al. (1999), dentre outros.

'Freitas (1991) descreveu que o pólen e o néctar das flores constituem praticamente a única fonte de alimento das abelhas, desde a fase larval à adulta.' Bastos (1998) citou que o pólen é o fornecedor natural de proteínas, graxas, vitaminas e sais minerais para as abelhas. Sendo a única fonte de alimento nitrogenado disponível para a alimentação das larvas; a ausência de pólen pode levar a colmeia à extinção.

Durkee (1971) \& Seijo et al.(1992) relataram que o conhecimento do grão de pólen fornece a origem botânica e geográfica da planta, aumentando assim a utilização desses recursos tróficos.

Bastos et al. (1995) estudaram o espectro polínico de amostras de méis da Serra de Caraça (Minas Gerais) e constataram a presença de plantas nativas na região, dentre as quais 23 são espécies típicas da área antrópica e quatro são espécies nativas presentes na mata primária existente da região. 
Brandão \& Bastos (1995) em méis produzidos na Serra da Piedade, em Caeté (MG), constataram que as diversas espécies botânicas apresentaram floração em distintas épocas apícolas do ano, cada qual com suas espécies mais importantes para as colônias (estação seca: Eucalyptus sp., estação de transição seca/chuva: Eucalyptus sp. e Vernonia scorpioides e estação chuvosa: Eucalyptus sp.).

Magalhães et al. (1996), em levantamento preliminar da flora apícola do sul da Bahia, registraram 24 plantas produtoras de pólen e ou néctar destacando-se nos mangues a Laguncularia racemosa, e nas restingas: Tapirina guianemsis, Coccoloba alnifolia, Cuphea sessifolia, Mimosa pudica, Byrsonima sericea, Crotalaria pallida, Turnera candida, Sesanum indicum, Argeratum conyzoides, Guapira pernambucensis, Ipomea pes-caprae, dentre outras, contribuindo assim para o desenvolvimento da apicultura da região.

Moreti et al. (1998) analisaram 14 amostras de méis do Estado da Bahia provenientes de apiários localizados em Cruz das Almas, Floresta Azul, Itaparica, Rio Real, Santo Antônio de Jesus e Sapeaçu. Foram encontrados 43 tipos polínicos sendo considerados como dominantes: em Cruz das Almas, Mimosa verrucata e Eucalyptus sp. em Floresta Azul, Bauhinia sp. e o tipo Caesalpiniaceae, em Itaparica, $M$. scabrella, em Rio Real, M. scabrella e Eucalyptus sp., em Santo Antônio de Jesus, $M$. scabrella e em Sapeaçu, $M$. verrucata e M. scabrella.

Al-Khalifa \& Al-Arify (1999) estudaram o espectro polínico de amostras de méis da Arábia Saudita e constataram que os pólens que foram encontrados com maior freqüência foram os das famílias Rhamnaceae, Leguminosae, Malvaceae, Labiatae, Gutteferae e Helianthemum.

Andrade et al. (1999) avaliaram o espectro polínico de amostras de méis de Portugal e constataram a presença de Eucalyptus globulus L. em todas as amostras e baixa porcentagem de pólen de Ericaceae. 
Costa et al. (1999) determinaram a origem botânica de amostras de méis brasileiros e constataram que $16 \%$ das amostras analisadas eram do tipo extra-floral, além de unifloral, bifloral e multifloral.

Moreti et al. (2000) em 94 amostras de méis do Estado de São Paulo declarados como méis silvestres constataram que 5 amostras eram de méis de eucaliptos, 1 amostra de mel de citros, 12 amostras apresentavam como pólen dominante um tipo pertencente às plantas silvestres (Cecropia, Bidens, Mimosa scabrella, Acacia, tipo Palmae) e as restantes (76) , uma mistura sem dominância de um tipo polínico.

$\mathrm{Na}$ região litoral norte do Estado da Bahia, apesar da sua diversidade floral e do potencial para exploração apícola, existem poucas informações sobre as plantas melíferas e as características físico-químicas do mel produzido. 


\section{MATERIAL E MÉTODOS}

As análises físico-químicas e polínicas dos méis, produzidos por Apis mellifera L. 1758 (Hymenoptera: Apidae), foram realizadas no laboratório de Insetos Úteis do Departamento de Entomologia, Fitopatologia e Zoologia Agrícola da Escola Superior de Agricultura "Luiz de Queiroz", campus de Piracicaba da Universidade de São Paulo.

As amostras de méis foram obtidas diretamente de apicultores da região litoral norte do Estado da Bahia, provenientes dos municípios de Alagoinhas ( $12^{\circ} 08^{\prime} \mathrm{S}, 38^{\circ} 26^{\prime} \mathrm{W}$; altitude $\left.150 \mathrm{~m}\right)$, Catu (12 $21^{\circ} \mathrm{S}, 38^{\circ} 23^{\prime} \mathrm{W}$; altitude

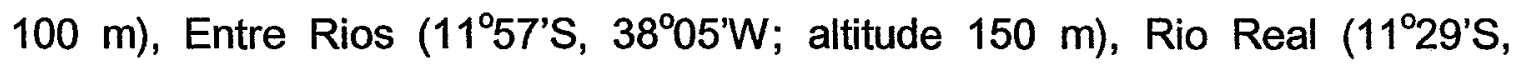

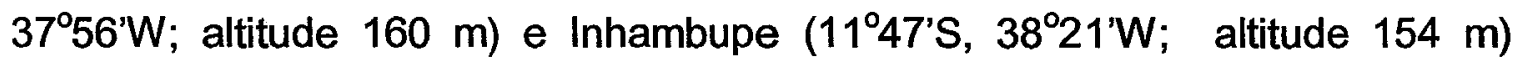
colhidas entre 01/1999 a 06/2000, num total de 36 amostras (Figura 1).

As análises físico-químicas realizadas foram: umidade (\%), cor $(\mathrm{mm})$, proteína $(\%), \mathrm{pH}$, acidez (meq/kg), índice de formol $(\mathrm{ml} / \mathrm{kg})$, condutividade elétrica $(\mu S)$, cinzas (\%), número de diastase (escala de Gothe), hidroximetilfurfural $(\mathrm{mg} / \mathrm{kg})$, açúcares redutores $(\%)$, açúcares totais $(\%)$, sacarose (\%) e análise de pólen (análise polínica).

Os dados obtidos foram avaliados por análise estatística e as informações geradas foram comparadas com as especificações estabelecidas pela legislação brasileira (Brasil, 1997) e internacional (Bogdavov et al., 1997) (Tabela 1). 


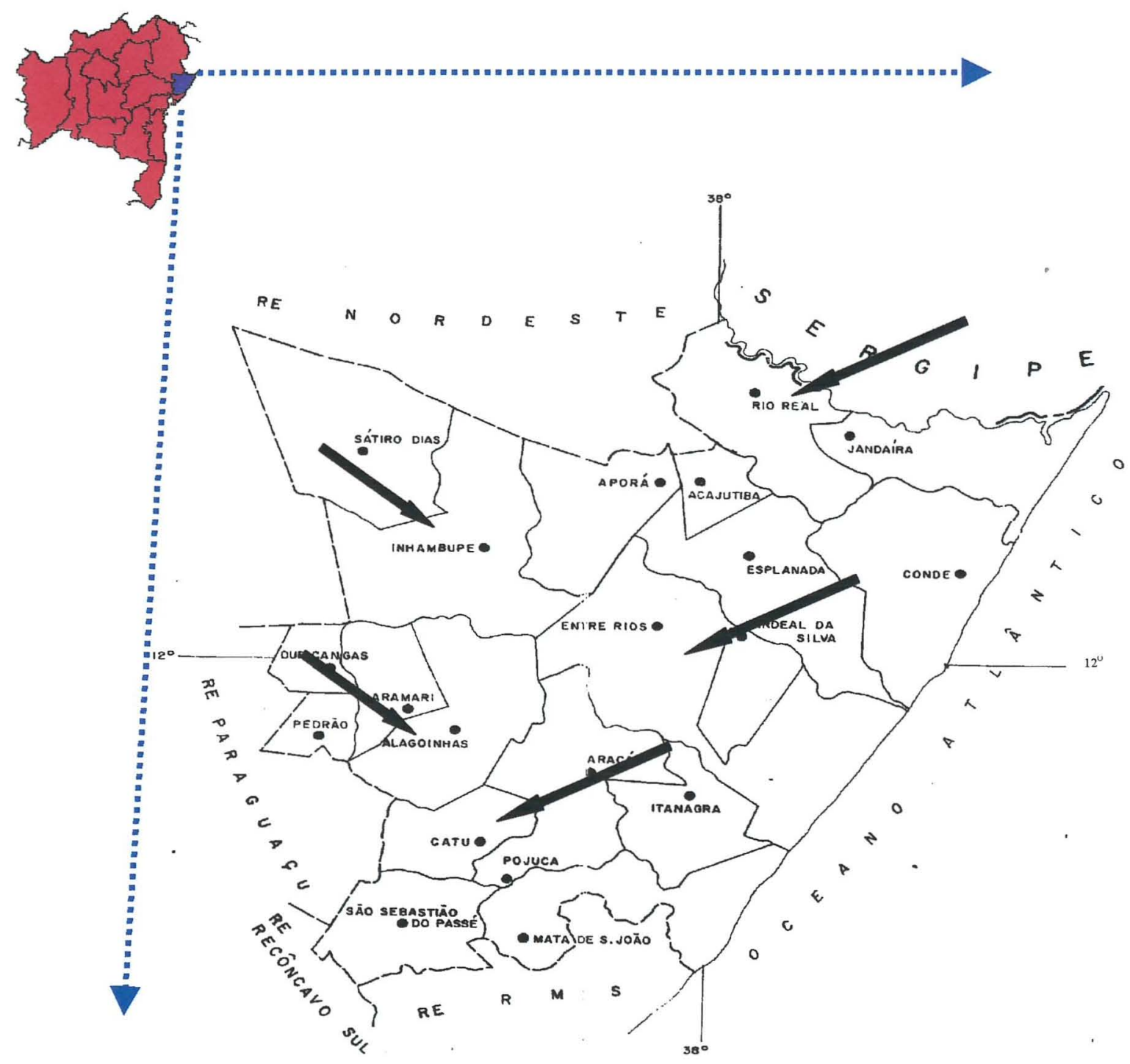

Figura 1- Estado da Bahia e região do litoral norte, com os seus respectivos municípios (Anuário Estátistico do Brasil, 1995). 
Tabela 1. Especificações estabelecidas pela legislação brasileira e internacional como parâmetros para análise de mel.

\begin{tabular}{lll}
\hline Parâmetros & $\begin{array}{l}\text { Especificações } \\
\text { Brasileira }\end{array}$ & $\begin{array}{l}\text { Especificações } \\
\text { Internacionais }\end{array}$ \\
\hline $\begin{array}{l}\text { Umidade } \\
\text { Cor }\end{array}$ & $\begin{array}{l}\text { Máxima de 20\% } \\
\text { De incolor a pardo escuro }\end{array}$ \\
Proteína & & $0,26 \%$ \\
Acidez & 3,3 a 4,6 & \\
$\begin{array}{l}\text { Índice de formol } \\
\text { Condutividade elétrica }\end{array}$ & Máxima de $40 \mathrm{meq} / \mathrm{kg}$ & 200 a $800 \mu \mathrm{S}$ \\
Cinzas & 4,5 a $15,0 \mathrm{~m} / \mathrm{kg}$ & \\
Número de diastase & & \\
Hidroximetilfurfural & $0,6 \%$ & \\
Açúcares redutores & Mínimo de $8(\mathrm{Gothe})$ ou $3, \mathrm{se} \mathrm{HMF<15}$ & \\
Sacarose & Mínima de $65 \%$ & \\
\hline
\end{tabular}

Fonte: Brasil (1997); Bogdanov et al. (1997).

Os valores citados na Tabela 1 foram estabelecidos como requisitos para consumo humano do mel, destinado ao comércio nacional e internacional. 


\subsection{Análises físico-químicas}

\subsubsection{Umidade}

A umidade dos diferentes méis foi determinada por meio de um refratômetro manual ATAGO específico para mel. Este aparelho foi adaptado a partir do refratômetro Abbe e possui um alto contraste no campo de visão (ATAGO Co., 1988).

\subsubsection{Cor}

Para a determinação da cor do mel utilizou-se o colorímetro de Pfund (Brice et al., 1956). As leituras foram feitas logo após a colheita do mel.

\subsubsection{Proteína}

A proteína do mel foi determinada seguindo-se as normas analíticas do Instituto Adolfo Lutz (Pregnolato, 1985).

\subsection{4 pH, acidez e índice de formol}

$\mathrm{O} \mathrm{pH}$, a acidez $\mathrm{e}$ o índice de formol foram determinados segundo a metodologia adotada pelo Laboratório do Centro de Apicultura Tropical do Instituto de Zootecnia de Pindamonhangaba, SP (Moraes \& Teixeira, 1998). 


\subsubsection{Número de diastase}

O número de diastase foi determinado conforme a metodologia de Schade (1958), modificada por Bagdanov et al. (1997).

\subsubsection{Hidroximetilfurfural}

O hidroximetilfurfural foi determinado conforme a metodologia de White (1979), modificada por Bagdanov et al. (1997).

\subsubsection{Cinzas}

A determinação de cinzas foi realizada por meio da calcinação em mufla a $550^{\circ} \mathrm{C}$ até um peso constante (Bogdanov et al., 1997).

\subsubsection{Condutividade elétrica}

A condutividade elétrica foi obtida em uma solução a $20 \%$ de matéria seca de mel a $20^{\circ} \mathrm{C}$ (Rendón, 1996). Para sua determinação foi utilizado um condutivímetro HANNA HI $8820 \mathrm{~N}$ - DIGIMED.

\subsubsection{Açúcares totais, açúcares redutores e sacarose}

A determinação de açúcares totais (\%), açúcares redutores (\%) e sacarose (\%) foi realizada por meio do método estabelecido por Somogyi (Nelson, 1944). 


\subsection{Análises polínicas}

A análise polínica constituiu-se da aplicação de dois métodos diferentes:

\subsubsection{Método qualitativo}

Determinou-se o tipo polínico presente no mel por meio do método de acetólise descrito por Louveaux et al. (1978), modificado por Iwana \& Mehlem (1979).

\subsubsection{Método quantitativo}

Após o reconhecimento do tipo polínico, processou-se a análise quantitativa, a qual foi realizada por meio da contagem consecutiva de 200 grãos de pólen, onde foram determinadas as seguintes classes de freqüência: pólen dominante (PD) (mais de $45 \%$ do total); pólen acessório (PA) (16\% a $45 \%)$; pólen isolado importante (Pli) (3\% a 15\%) e pólen isolado ocasional (Plo) (menor que 3\%) (Louveaux et al., 1978).

\section{3 Análise dos dados}

Os dados foram processados usando o SAS (1990), obtendo as médias, desvio padrão das médias das amostras, as análises multivariadas de Cluster e componentes principais. 


\section{RESULTADO E DISCUSSÃO}

\subsection{Análises físico-químicas}

Os resultados dos parâmetros físico-químicos analisados em 36 amostras de méis, provenientes da região litoral norte do Estado da Bahia estão apresentados na Tabela 2. 
Tabela 2. Valores médios encontrados nas análises físico-químicas de 36 amostras de méis de Apis mellifera, da região litoral norte da Bahia.

\begin{tabular}{|c|c|c|c|c|c|c|}
\hline Amostras & $\begin{array}{c}\text { Umidade } \\
(\%)\end{array}$ & $\begin{array}{c}\text { Cor } \\
(\mathrm{mm})\end{array}$ & $\begin{array}{c}\text { Proteína } \\
(\%)\end{array}$ & $\mathrm{pH}$ & $\begin{array}{c}\text { Acidez } \\
(\mathrm{meq} / \mathrm{kg})\end{array}$ & $\begin{array}{r}{ }^{*} \mathrm{IF} \\
(\mathrm{ml} / \mathrm{kg})\end{array}$ \\
\hline 1 & 20,00 & ÅMBAR CLARO & 0,29970 & 3,58 & 34,33 & 6,33 \\
\hline 2 & 20,00 & ÂMBAR CLARO & 0,14691 & 4,05 & 32,33 & 4,00 \\
\hline 3 & 20,01 & ÂMBAR & 0,27996 & 3,98 & 39,33 & 9,67 \\
\hline 4 & 20,00 & ÂMBAR & 0,97100 & 3,98 & 40,00 & 19,00 \\
\hline 5 & 20,05 & ÂMBAR CLARO & 0,27724 & 4,18 & 21,33 & 3,33 \\
\hline 6 & 19,90 & ÂMBAR CLARO & 0,11186 & 4,28 & 20,67 & 1,67 \\
\hline 7 & 19,33 & ÂMBAR CLARO & 0,14973 & 4,17 & 16,67 & 1,67 \\
\hline 8 & 19,53 & ÂMBAR CLARO & 0,08197 & 4,13 & 27,67 & 3,17 \\
\hline 9 & 19,80 & ÂMBAR & 0,46194 & 3,74 & 37,33 & 12,00 \\
\hline 10 & 19,93 & ÂMBAR CLARO & 0,22315 & 3,39 & 43,00 & 7,67 \\
\hline 11 & 20,00 & ÂMBAR & 0,35924 & 3,65 & 39,00 & 8,67 \\
\hline 12 & 20,02 & ÂMBAR CLARO & 0,11445 & 4,07 & 24,67 & 3,00 \\
\hline 13 & 20,00 & ÂMBAR CLARO & 0,10512 & 4,22 & 24,33 & 4,33 \\
\hline 14 & 20,00 & ÂMBAR CLARO & 0,23282 & 3,46 & 34,53 & 11,00 \\
\hline 15 & 20,05 & ÂMBAR CLARO & 0,10909 & 4,00 & 29,33 & 6,67 \\
\hline 16 & 18,00 & ÂMBAR CLARO & 0,24756 & 3,62 & 22,67 & 12,67 \\
\hline 17 & 20,02 & ÂMBAR CLARO & 0,18556 & 3,54 & 13,67 & 11,00 \\
\hline 18 & 20,00 & ÂMBAR CLARO & 0,24849 & 3,53 & 29,00 & 11,67 \\
\hline 19 & 19,20 & ÂMBAR & 0,17509 & 3,62 & 22,67 & 11,67 \\
\hline 20 & 19,40 & ÂMBAR CLARO & 0,18473 & 3,58 & 32,67 & 10,33 \\
\hline 21 & 20,07 & EXTRA BRANCO & 0,05629 & 3,37 & 17,67 & 6,33 \\
\hline 22 & 19,67 & Â. EXTRA CLARO & 0,14694 & 3,56 & 27,00 & 9,33 \\
\hline 23 & 19,00 & ÂMBAR CLARO & 0,24808 & 3,83 & 35,33 & 10,67 \\
\hline 24 & 19,47 & ÂMBAR CLARO & 0,20183 & 3,72 & 31,67 & 8,67 \\
\hline 25 & 18,20 & ÂMBAR CLARO & 0,19217 & 3,58 & 39,00 & 10,33 \\
\hline 26 & 18,27 & ÂMBAR CLARO & 0,21985 & 3,58 & 39,00 & 8,33 \\
\hline 27 & 19,73 & ÂMBAR CLARO & 0,15657 & 3,59 & 34,67 & 11,33 \\
\hline 28 & 21,40 & ÂMBAR CLARO & 0,39000 & 3,49 & 14,33 & 13,00 \\
\hline 29 & 21,90 & ÂMBAR CLARO & 0,21000 & 3,57 & 13,00 & 29,00 \\
\hline 30 & 22,90 & ÂMBAR CLARO & 0,32000 & 4,46 & 14,33 & 10,67 \\
\hline 31 & 18,00 & ÂMBAR CLARO & 0,13732 & 3,54 & 33,00 & 6,00 \\
\hline 32 & 19,20 & ÂMBAR CLARO & 0,06129 & 3,65 & 33,67 & 4,67 \\
\hline 33 & 17,66 & ÂMBAR CLARO & 0,14682 & 3,47 & 29,67 & 3,00 \\
\hline 34 & 19,33 & ÂMBAR CLARO & 0,50556 & 3,73 & 30,00 & 10,00 \\
\hline 35 & 19,73 & ESCURO & 0,83611 & 3,92 & 40,00 & 20,00 \\
\hline 36 & 18,47 & ÂMBAR & 0,51042 & 4,00 & 30,00 & 11,00 \\
\hline
\end{tabular}


Tabela 2. Valores médios encontrados nas análises físico-químicas de 36 amostras de méis de Apis mellifera, da região litoral norte da Bahia.

\begin{tabular}{|c|c|c|c|c|c|c|c|}
\hline Amostras & $\begin{array}{l}\text { *N D } \\
\text { (Gothe) }\end{array}$ & $\begin{array}{c}{ }^{*} \mathrm{HMF} \\
(\mathrm{mg} / \mathrm{kg})\end{array}$ & $\begin{array}{c}\text { Cinzas } \\
(\%)\end{array}$ & $\begin{array}{l}{ }^{*} \mathrm{CE} \\
(\mu \mathrm{S})\end{array}$ & $\begin{array}{l}{ }^{*} \mathrm{AT} \\
\text { (\%) }\end{array}$ & $\begin{array}{l}{ }^{*} \mathrm{AR} \\
\text { (\%) }\end{array}$ & $\begin{array}{l}{ }^{*} S \\
(\%)\end{array}$ \\
\hline 1 & 31,00 & 74,85 & 0,265795 & 430,67 & 71,75 & 69,60 & 2,05 \\
\hline 2 & 18,64 & 63,22 & 0,468446 & 1102,33 & 71,51 & 70,40 & 1,06 \\
\hline 3 & 30,00 & 136,68 & 0,369465 & 672,33 & 73,26 & 69,75 & 3,34 \\
\hline 4 & 62,81 & 109,58 & 0,436441 & 1494,67 & 69,05 & 65,21 & 3,65 \\
\hline 5 & 38,43 & 16,77 & 0,384377 & 1022,67 & 72,96 & 71,75 & 1,15 \\
\hline 6 & 20,05 & 5,34 & 0,435092 & 1142,67 & 70,03 & 69,17 & 0,82 \\
\hline 7 & 39,67 & 6,84 & 0,529202 & 1146,00 & 73,86 & 71,29 & 2,44 \\
\hline 8 & 36,40 & 3,99 & 0,532324 & 1216,67 & 71,23 & 68,55 & 2,55 \\
\hline 9 & 27,68 & 49,95 & 0,357803 & 933,33 & 75,62 & 68,89 & 6,39 \\
\hline 10 & 40,24 & 20,16 & 0,298952 & 481,67 & 73,88 & 68,89 & 4,73 \\
\hline 11 & 19,30 & 44,66 & 0,301924 & 637,00 & 74,27 & 69,82 & 4,23 \\
\hline 12 & 24,45 & 18,86 & 0,346990 & 1117,33 & 70,86 & 69,76 & 1,05 \\
\hline 13 & 39,66 & 2,30 & 0,435497 & 1303,67 & 70,30 & 69,53 & 0,73 \\
\hline 14 & 25,42 & 18,26 & 0,284933 & 311,00 & 70,67 & 69,53 & 1,09 \\
\hline 15 & 22,64 & 6,49 & 0,474053 & 1100,67 & 71,04 & 70,47 & 0,54 \\
\hline 16 & 37,50 & 28,99 & 0,269232 & 304,67 & 71,05 & 70,19 & 0,81 \\
\hline 17 & 45,33 & 16,87 & 0,274379 & 361,67 & 73,76 & 72,53 & 1,17 \\
\hline 18 & 35,15 & 16,17 & 0,367093 & 371,67 & 71,57 & 69,85 & 1,64 \\
\hline 19 & 27,61 & 10,58 & 0,295209 & 562,33 & 75,33 & 70,75 & 4,36 \\
\hline 20 & 54,99 & 18,26 & 0,257632 & 509,67 & 71,47 & 69,78 & 1,61 \\
\hline 21 & 32,67 & 8,83 & 0,094312 & 208,67 & 74,91 & 71,97 & 2,79 \\
\hline 22 & 37,40 & 9,73 & 0,107948 & 486,67 & 75,99 & 71,59 & 4,18 \\
\hline 23 & 62,51 & 11,98 & 0,277332 & 795,67 & 71,86 & 70,15 & 1,63 \\
\hline 24 & 56,70 & 1,50 & 0,226352 & 675,67 & 68,70 & 65,50 & 3,04 \\
\hline 25 & 20,60 & 24,50 & 0,318481 & 815,67 & 70,90 & 70,51 & 0,38 \\
\hline 26 & 29,25 & 18,61 & 0,204748 & 584,33 & 70,34 & 69,56 & 0,74 \\
\hline 27 & 29,83 & 19,46 & 0,209494 & 583,00 & 73,69 & 69,12 & 4,34 \\
\hline 28 & 25,46 & 12,86 & 0,370608 & 271,67 & 70,17 & 66,82 & 3,18 \\
\hline 29 & 16,66 & 22,46 & 0,450588 & 692,67 & 66,96 & 59,18 & 7,39 \\
\hline 30 & 34,17 & 8,26 & 0,665464 & 1269,67 & 66,05 & 65,38 & 0,64 \\
\hline 31 & 32,00 & 15,32 & 0,252402 & 735,33 & 72,95 & 72,13 & 0,78 \\
\hline 32 & 35,18 & 18,43 & 0,329873 & 975,67 & 71,86 & 70,90 & 0,92 \\
\hline 33 & 34,15 & 14,83 & 0,189699 & 657,67 & 72,45 & 69,85 & 2,47 \\
\hline 34 & 41,00 & 4,45 & 0,323730 & 629,00 & 72,85 & 71,62 & 1,17 \\
\hline 35 & 34,13 & 7,70 & 0,668227 & 1635,00 & 66,14 & 61,70 & 4,22 \\
\hline 36 & 29,40 & 8,09 & 0,390903 & 869,00 & 72,76 & 69,45 & 3,15 \\
\hline
\end{tabular}


*I. F. = índice de formol, ND = número de diastase, HMF = hidroximetilfurfural, $\mathrm{CE}=$ condutividade elétrica, $\mathrm{AT}=$ açúcares totais $\mathrm{AR}=$ açúcar redutor, $\mathrm{S}=$ sacarose.

$\mathrm{Na}$ Tabela 3 observa-se os valores estabelecidos pelas normas vigentes, as médias, os desvios padrão das médias, os valores máximo e mínimo de cada um dos parâmetros.

Tabela 3. Valores médio e o desvio padrão da média encontrados nas análises físico-químicas de 36 amostras de méis de Apis mellifera, do litoral norte do Estado da Bahia.

\begin{tabular}{|c|c|c|c|c|c|}
\hline Parâmetros analisados & Norma vigente & & édia & Máximo & Mínimo \\
\hline Umidade \% & Máxima 20 & 19,77 & $0,77^{*}$ & 17,66 & 22,9 \\
\hline Proteína \% & Máximo 0,26 & 0,26 & $0,13^{*}$ & 0,056 & 0,971 \\
\hline $\mathrm{PH}$ & $3,3-4,6$ & 3,77 & $0,25^{*}$ & 3,37 & 4,46 \\
\hline Acidez meq/kg & Máxima 40 & 29,10 & $7,04^{*}$ & 13 & 43 \\
\hline Índice de formol $\mathrm{ml} / \mathrm{kg}$ & $4,5-15$ & 9,22 & $3,84^{*}$ & 1,67 & 29 \\
\hline Número de diastase (Gothe) & Mínimo 8 & 34,11 & $8,41^{*}$ & 16,66 & 62,81 \\
\hline HMF mg/Kg & Máximo 40 & 24,33 & $\pm 18,77^{*}$ & 1,5 & 136 \\
\hline Açúcares redutores \% & Mínimo 65 & 69,20 & $1,82^{*}$ & 61,7 & 72,53 \\
\hline Sacarose \% & Máximo 5 & 2,40 & $1,42^{*}$ & 0,38 & 7,39 \\
\hline Açúcares totais & - & 71,72 & $1,83^{*}$ & 66,05 & 75,62 \\
\hline Condutividade elétrica $\mu S$ & $200-800$ & 780,7 & $\pm 302,70^{*}$ & 271,67 & 1634 \\
\hline Cinzas \% & Máximo 0,6 & 0,3 & $0,10^{*}$ & 0,094 & 0,668 \\
\hline
\end{tabular}

* desvio padrão da média

Os valores médios obtidos estão de acordo com as normas vigentes, e estão próximos aos de White Júnior \& Rudyj (1978); Pamplona. (1989); Baldi Coronel et al. (1993); Horn te al. (1996); Komatsu (1996); Carvalho et al. (1998, 2000) e Unãtes et al. (1999). 


\subsubsection{Umidade}

A umidade (\%) para as 36 amostras de méis analisadas variaram de 17,66 a 22,9\%, com uma média de 19,77\% (Tabelas 2 e 3) a qual está dentro do limite permitido pela norma vigente que é de $20 \%$.

A Figura 2 representa as 36 amostras em porcentagem que são aceitas $(91,66 \%)$ e não aceitas $(8,33)$ pela legislação brasileira.

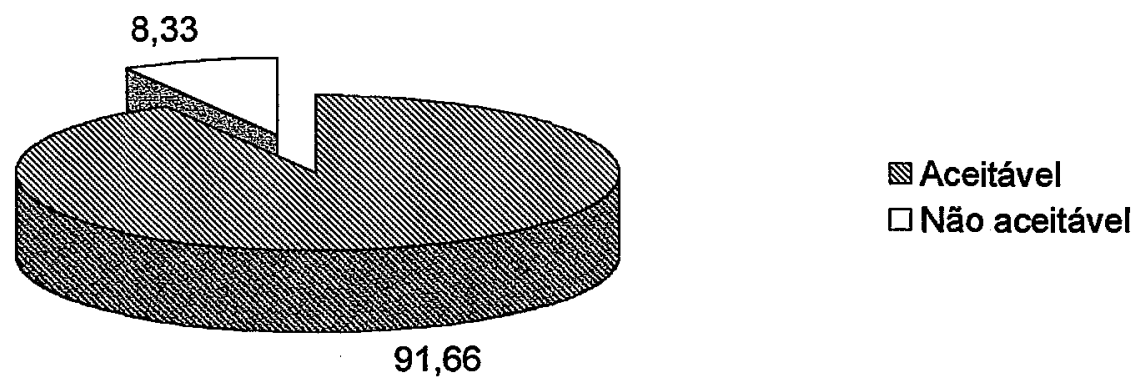

Figura 2 - Porcentagem de amostras que apresentam umidade aceitável ou não aceitável segundo, a legislação brasileira, em 36 amostras de méis da região litoral norte do Estado da Bahia.

Os valores obtidos estão próximos aos de Horn et al. (1996) que analisando amostras de méis do Brasil constataram valor médio para a umidade de $18,7 \%$. Entretanto, encontraram no Estado da Bahia amostras com $22,4 \%$ de umidade. Conforme o autor, isto confirma a observação dos apicultores, que méis da região nordeste são mais líquido. Carvalho et al. (1998) constataram em amostras de méis da Bahia valores médios de $21,58 \%$ de umidade.

Pamplona (1989) trabalhando com méis brasileiros de Apis mellifera, constatou como média geral das amostras $17,9 \%$ e para região nordeste valor médio de $21,5 \%$ de umidade. Costa et al. (1999) trabalharam com amostras de méis de alguns estados brasileiros e encontrou valor médio de $18,37 \%$. Entretanto, para o Estado da Paraíba (Nordeste) os valores variaram de $21-23 \%$. 
Komatsu (1996) analisando amostras de méis do Estado de São Paulo, encontrou valores para a umidade variando de 16,4 a $23,4 \%$.

\title{
4.1.2 Cor
}

As cores das 36 amostras de méis analisadas são apresentadas na Tabela 2 e as porcentagens de amostras classificadas nas diferentes cores na Figura 3.

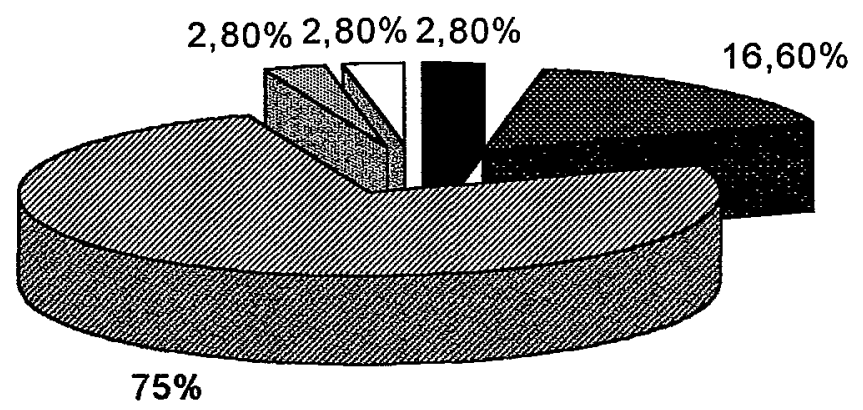

\author{
mESCURO \\ 圈ÂMBAR \\ ØÂMBAR CLARO \\ TAMBARAR EXTRA CLARO \\ I EXTRA BRANCO
}

Figura 3- Porcentagem de amostras classificadas nas diferentes classes de cor, em 36 amostras de méis de Apis mellifera, da região litoral norte do Estado da Bahia.

Observou-se, para as amostras analisadas, uma predominância da cor âmbar claro (75\%) sendo ainda encontrado âmbar $(16,6 \%)$, escuro $(2,8 \%)$, âmbar extra claro $(2,8 \%)$ e extra branco (2,8\%) (Figura 2$)$. As cores encontradas estão dentro da norma vigente que pode variar desde o branco água até o âmbar escuro (Brasil, 1997). Smith (1967) relata que o tempo de estocagem, a luz, o calor e as possiveis reações enzimáticas podem afetar esta propriedade física. 
Segundo Seemann \& Neira (1988) a cor do mel está relacionada com a sua origem floral, e é influenciada por fatores climáticos durante o fluxo do néctar e a temperatura da colméia.

A predominância da cor âmbar claro obtida nas amostras de méis da região litoral norte do Estado da Bahia coincide com as de Carvalho et al. (2000) que também constataram a predominância da cor âmbar claro.

Baldi Coronel et al. (1993) em trabalho realizado com amostras de méis da Argentina constataram a predominância da cor âmbar claro.

Escobar-Martínez et al. (1992) analisando amostras de méis do Paraguai também encontraram a predominância da cor âmbar claro.

\subsubsection{Proteína}

O conteúdo de proteínas para as 36 amostras de méis analisadas variaram de 0,056 a $0,971 \%$ (Tabelas 2 e 3 ). $\mathrm{O}$ valor médio de $0,26 \%$ obtido encontra-se dentro dos padrões internacionais que é de $0,26 \%$ (Tabela 3).

Observou-se que $78 \%$ (Figura 4) das amostras de méis analisadas estão dentro do limite estabelecido. 


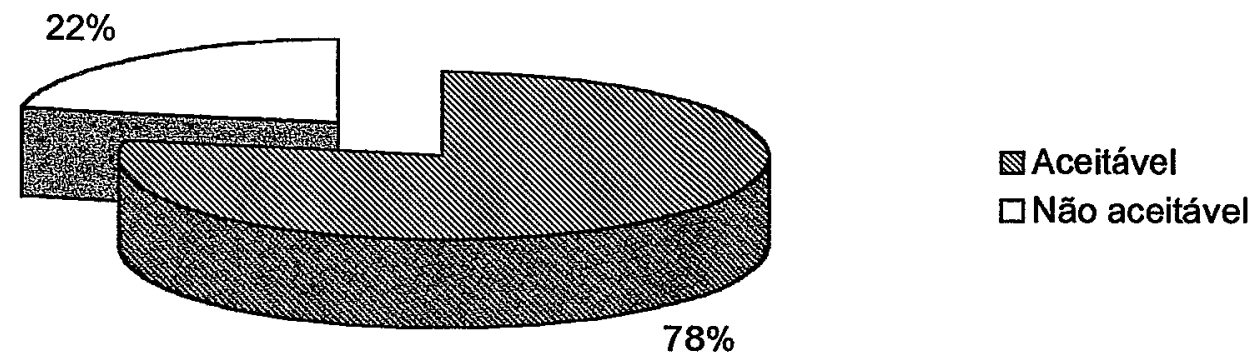

Figura 4 - Porcentagem de amostras que apresentam proteína aceitável ou não aceitável, segundo a legislação internacional, em 36 amostras de méis da região litoral norte do Estado da Bahia.

Os valores obtidos estão semelhantes aos de White Júnior \& Rudyj (1978) que encontraram nos Estados Unidos variação de 0,2 a 0,99\% para o teor de proteína. Carvalho et al. (1998) encontraram em amostras de méis do Estado da Bahia valor médio de $0,44 \%$ para a proteína.

Conforme Bath \& Singh (1999) a variação para o valor de proteína ocorre em função da origem floral. Os autores constataram 0,036 e 0,65\% para flores de Helianthus annuus e Eucalyptus lanceolatus, respectivamente. Peng \& Pan (1994) encontraram para flores de Ziziphus jujuba, Astragalus sinicus, Sesame sp., flor de algodão dentre outras, variações entre 0,048 a 0,42\%.

\subsection{4 pH}

$\mathrm{O} \mathrm{pH}$ das 36 amostras de méis analisadas variaram de 3,37 a 4,46 , com um valor médio de 3,77 (Tabelas 2 e 3 ). Os valores encontrados para o pH em $100 \%$ das amostras estão dentro da norma vigente que é de 3,3 a 4,6 (Figura 5). 


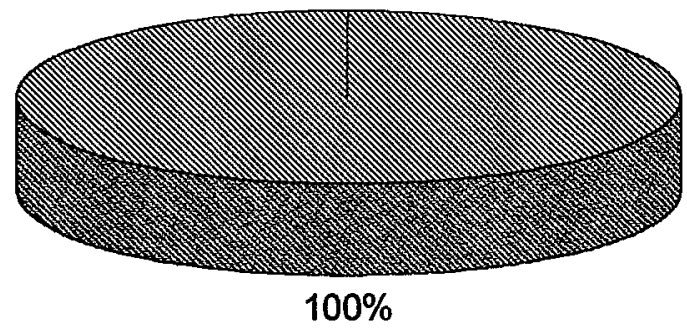

$\mathbb{N}$ Aceitável

Figura 5 - Porcentagem de amostras que apresentaram $\mathrm{pH}$ aceitável, segundo a legislação brasileira, em 36 amostras de méis da região litoral norte do Estado da Bahia.

Os valores encontrados são bastante próximos aos constatados por Azeredo et al. (1999) que em amostras de méis de São Fidélis (RJ) obtiveram valores médios de $\mathrm{pH} 3,65$.

Os maiores valores para o $\mathrm{pH}$ foram obtidos em amostras de méis de flor de eucaliptos (amostras $2,5,6,7,8,12,13,15,30$ ), com uma média de 4,07. Flechtmann et al. (1963) obtiveram valor médio de 4,1 para méis de flor de eucaliptos.

Horn et al. (1996) analisaram amostras de méis brasileiros e constataram uma média de 3,8 por estado e de 3,9 por região. Os autores citaram que o maior valor de $\mathrm{pH}$ foi obtido na região sul $(4,3)$ e o menor valor na região nordeste $(3,4)$.

Andrade et al. (1999) encontraram em méis portugueses valores de $\mathrm{pH}$ variando de 3,6 a 4,46.

Baldi Coronel et al. (1993), em amostras de méis de Entre Rios (Argentina), obtiveram valores variando entre 3 a 5 .

Pamplona (1989) analisando amostras de méis brasileiros encontrou valores variando de 3,10 a 5,3 , obtendo como valor médio $\mathrm{pH}$ de 3,81 . 


\section{5 Acidez}

A acidez das 36 amostras de méis analisadas apresentaram valores variando de 13 a $43 \mathrm{meq} / \mathrm{kg}$ com uma média de 29,10 meq/kg (Tabelas 2 e 3). O valor médio encontrado para as amostras analisadas estão em conformidade com a norma vigente que é de no máximo $40 \mathrm{meq} / \mathrm{kg}$.

Na Figura 6 observa-se que $97 \%$ das amostras estavam dentro das especificações estabelecidas. Apenas uma amostra (3\%) apresentou valor acima da norma vigente (43 $\mathrm{meq} / \mathrm{kg})$.

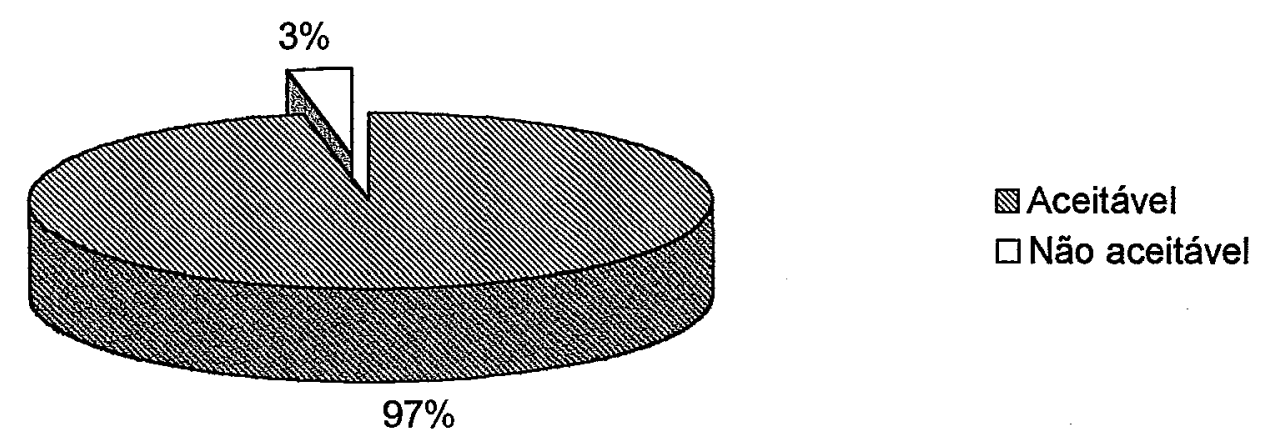

Figura 6 - Porcentagem de amostras que apresentaram acidez aceitável e não aceitável, segundo a legislação brasileira, em 36 amostras de méis da região litoral norte do Estado da Bahia.

Pamplona (1989) descreve que o ácido glucônico, formado através da glicose pela ação da enzima glicoseoxidase, tende sempre a aumentar, mesmo durante o armazenamento do mel, pois, esta enzima permanece em atividade no mel, mesmo após seu processamento. Desta forma, a acidez do mel aumenta durante o armazenamento e, consequentemente, o pH diminui.

Campos et al. (1999) analisando amostras de méis brasileiros encontraram valores variando de 8,20 a $50,0 \mathrm{meq} / \mathrm{kg}$. Carvalho et al. (2000) 
analisando méis do Estado da Bahia encontraram como acidez média 35,2 meq $/ \mathrm{kg}$, valor este próximo ao encontrado no presente trabalho.

\subsection{6 Índice de formol}

Os valores encontrados para o índice de formol das 36 amostras de méis analisadas variaram de 1,67 a $29 \mathrm{ml} / \mathrm{kg}$ com um valor médio de 9,22 (Tabelas 2 e 3). O valor médio das amostras analisadas está dentro da norma vigente que é de 4,5-15 ml/kg. Na Figura 7 observa-se a porcentagem das amostras que se enquadra na norma vigente.

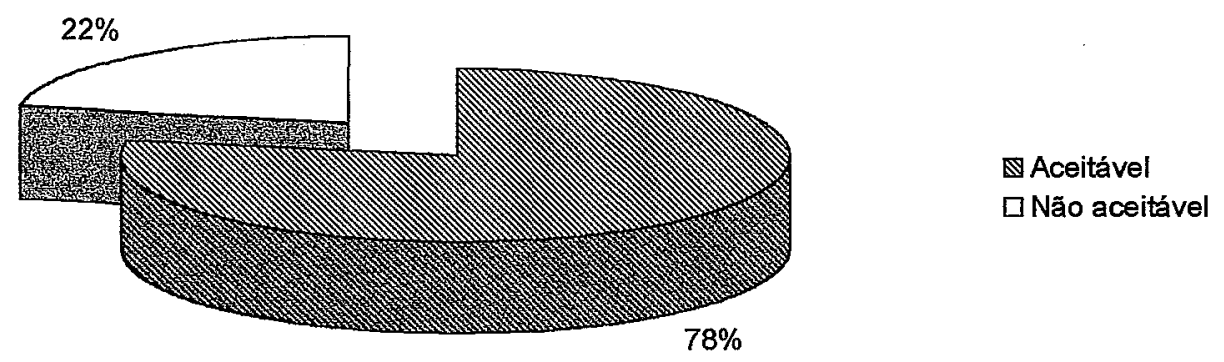

Figura 7 - Porcentagem de amostras que apresentaram índice de formol aceitável e não aceitável, segundo a legislação brasileira, em 36 amostras de méis da região litoral norte do Estado da Bahia.

O valor mais alto de índice de formol foi encontrado em amostras de méis de Mimosa verrucata, tipo Asteraceae e tipo Arecaceae (amostras 4, $29,35)$. $E$ os valores mais baixos foram encontrados em amostras de méis de flor de Eucalyptus sp. $(2,5,6,7,8,12,13)$ e em uma amostra de Psidium sp. (33).

Komatsu (1996) analisando amostras de méis do Estado de São Paulo encontrou para o índice de formol os seguintes valores médios: 13,9 (mel 
de cana-de-açúcar), 10,1 ( $m e l$ de flores silvestres), 6,9 (mel de flor de eucaliptos), 6,3 (mel de flor de laranjeira).

Temiz (1983) encontrou, na Turquia, em amostras recém-colhidas variações do índice de formol de 4,5 a $8,6 \mathrm{ml} / \mathrm{kg}$.

Carvalho et al. (1998) analisaram amostras de méis do Estado da Bahia e constataram um valor médio de $16,49 \mathrm{ml} / \mathrm{kg}$ para o índice de formol.

\subsubsection{Número de diastase}

O número de diastase das 36 amostras de méis analisadas variou de 16,66 a 62,81 (escala de Gothe) com valor médio de 34,11(escala de Gothe) (Tabelas 2 e 3 ).

Analisando-se os valores encontrados, verifica-se que todos os méis (100\%) estão de acordo com a norma vigente, ou seja, todos os valores encontram-se acima de 8 (escala de Gothe) que é o valor mínimo estabelecido (Figura 8).

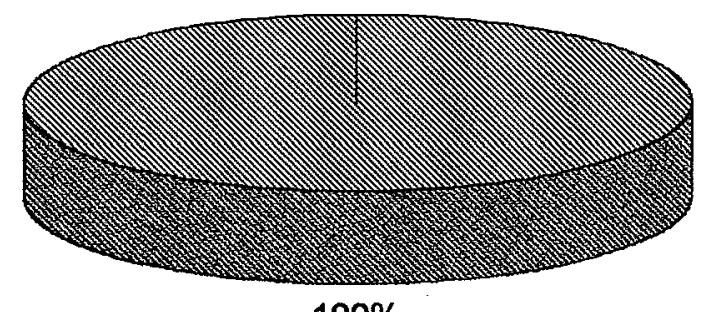

Aceitável

$100 \%$

Figura 8 - Porcentagem de amostras que apresentaram número de diastase aceitável, segundo a legislação brasileira, em 36 amostras de méis da região litoral norte do Estado da Bahia. 
Costa et al. (1999) encontraram em amostras de méis brasileiros de diferentes origens florais valores variando de 5,9 a 66,7 (escala de Gothe) para o número de diastase.

Andrade et al. (1999) encontraram em méis portugueses valores variando de 13 a 51,1 (escala de Gothe).

Persano-Oddo et al. (1990) estudando a presença de enzimas em méis uniflorais de diferentes origens botânicas encontraram valores para o número de diastase muito diferente dentro da mesma florada. Resultados semelhantes foram observados no presente trabalho (Tabela 2 ).

\subsubsection{Hidroximetilfurfural}

As quantidades de Hidroximetilfurfural (HMF) encontradas nas 36 amostras de méis analisadas, variaram de 1,5 a $136 \mathrm{mg} / \mathrm{kg}$, com o valor médio de $24,33 \mathrm{mg} / \mathrm{kg}$ (Tabelas 2 e 3 ).

Com base no valor médio encontrado para o HMF $100 \%$ das amostras analisadas no presente trabalho estão abaixo do valor máximo estabelecido pela norma vigente que é de $40 \mathrm{mg} / \mathrm{kg}$ (Tabela 3).

$\mathrm{Na}$ Figura 9 observa-se a porcentagem de méis (84\%) que enquadra-se na norma vigente. 


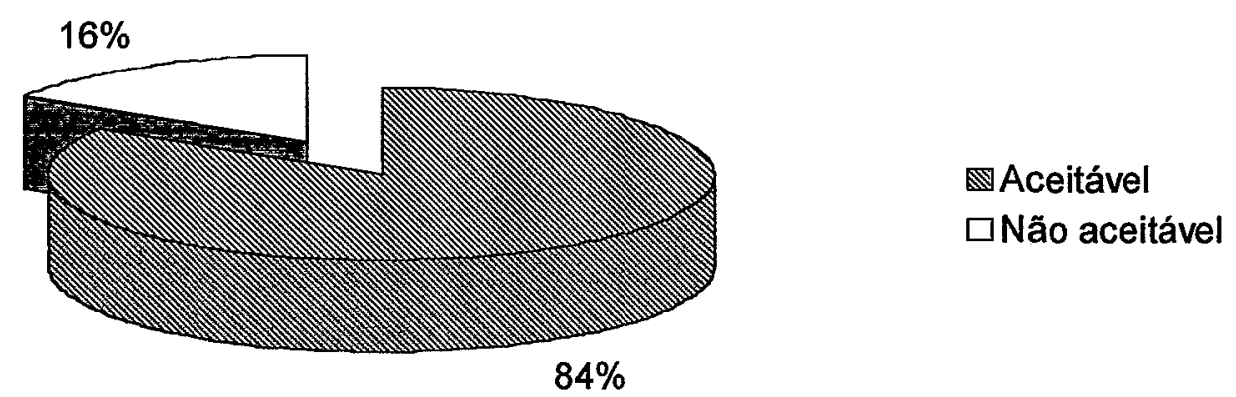

Figura 9 - Porcentagem de amostras que apresentaram Hidroximetilfurfural aceitável ou não aceitável, segundo a legislação brasileira, em 36 amostras de méis da região litoral norte do Estado da Bahia.

Dayrell \& Vital (1991) analisaram amostras de méis brasileiros pelo método AOAC encontraram valores variando de 1,1 a $248,2 \mathrm{mg} / \mathrm{kg}$. Os autores mencionam que os méis de países tropicais possuem alto teor de HMF, tornando-se fundamental a quantificação desse componente para a verificação da qualidade do produto.

Horn et al. (1996) analisando amostras de méis brasileiros encontraram para a região nordeste valor médio de 113,7 , valor esse muito acima do estabelecido pela norma vigente.

Semelhantemente aos altos valores encontrados no presente estudo, Mendes et al. (1998) também determinaram para méis portuguêses valores de 1,7 a $94,9 \mathrm{mg} / \mathrm{kg}$.

O HMF no mel é um indicador de superaquecimento, armazenamento e adulteração com açúcar invertido. White Júnior (1992) menciona que méis de países subtropicais pode ter naturalmente um alto conteúdo de HMF sem que o mel tenha sido superaquecido ou adulterado, devido as altas temperaturas. 


\subsubsection{Cinzas}

Os valores de cinzas encontrados nas 36 amostras de méis analisadas, variaram de 0,094 a $0,67 \%$ com um valor médio de $0,35 \%$ (Tabelas 2 e 3). Desta forma observa-se que os valores médios obtidos estão de acordo com a legislação brasileira que estabelece o limite máximo de 0,6\%. Na Figura 10 representa a porcentagem das amostras de méis (94\%) que se enquadra nas normas vigente.

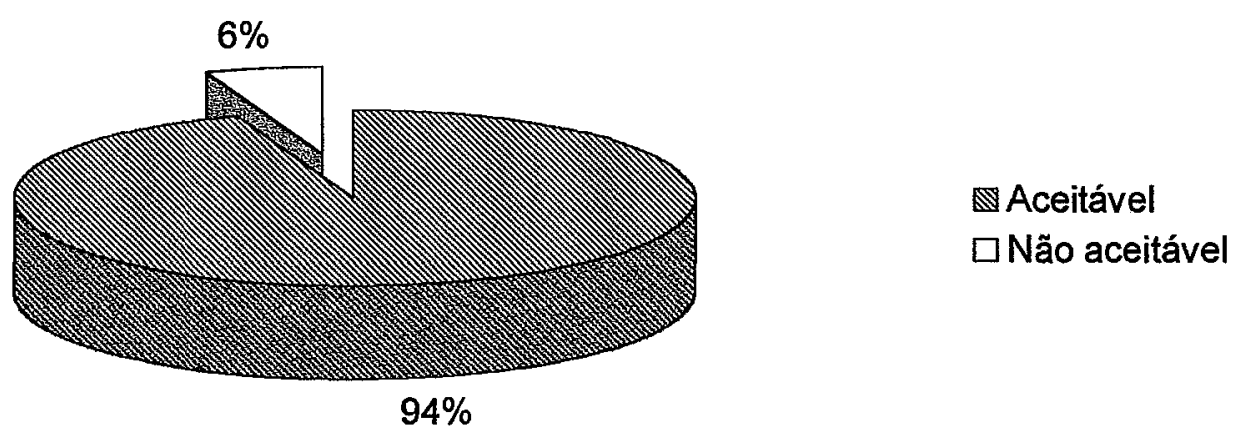

Figura 10 - Porcentagem de amostras que apresentaram teor de cinzas aceitável ou não aceitável, segundo a legislação internacional, em 36 amostras méis da região litoral norte do Estado da Bahia.

Bogdanov et al. (1999) mencionam que o conteúdo de cinzas é influenciado pela origem botânica. Lasceve \& Gonnet (1974) citam que além da origem botânica podem ocorrer variações por motivos relacionados às abelhas, ao apicultor e ao clima da região onde foi produzido.

Uñates et al. (1999) analisando amostras de méis de San Luis (Argentina) encontraram variação de 0,052 a $0,623 \%$. Baldi Coronel et al. (1993) também em méis da Argentina encontraram valores variando de 0,05 a $0,65 \%$. 


\subsubsection{Condutividade elétrica}

Os valores de condutividade elétrica para as 36 amostras de méis analisadas variaram de 271,67 a $1634 \mu \mathrm{S}$, com uma média em 780,7 $\mu \mathrm{S}$. (Tabelas 2 e 3). O valor médio observado para a condutividade elétrica encontra-se dentro das normas internacionais que é de 200 a $800 \mu \mathrm{S}$, no entanto, foram encontrados valores acima do estabelecido. Na Figura 11 observa-se que $61 \%$ das amostras enquadram-se nas normas internacionais.

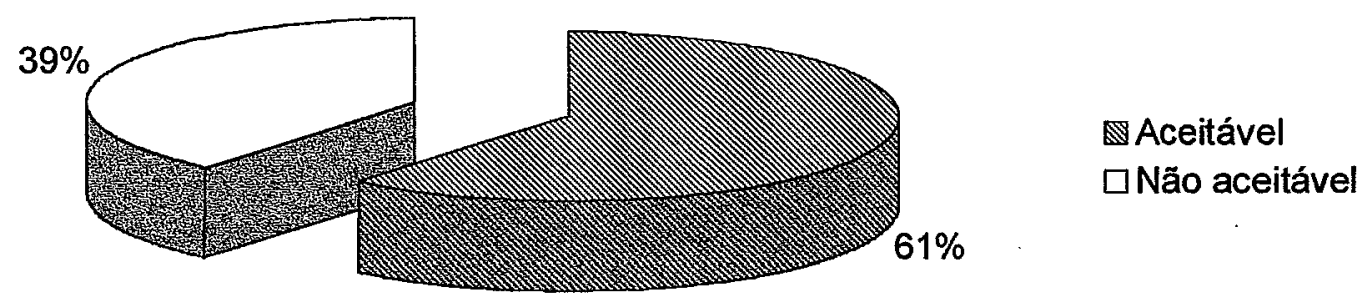

Figura 11 - Porcentagem de amostras que apresentaram condutividade elétrica aceitável ou não aceitável, segundo as normas internacionais, em 36 amostras méis da região litoral norte do Estado da Bahia.

Dentre as amostras que se encontram acima das normas internacionais foi observada a grande presença de méis de flor de eucaliptos (amostras 2, 5, 6, 7, 8, 12, 13, 15, 25, 30, 32) (Tabela 2). Segundo Bogdanov et al. (1997) para méis de flor de eucaliptos aceita-se de 200 a $1800 \mu S$ para a condutividade elétrica.

Os dados observados são semelhantes aos de Horn et al. (1996) que analisaram amostras de méis de diferentes regiões do Brasil e constataram para a condutividade elétrica valores variando de 100 a $2103 \mu$ S. 
Persano-Oddo et al. (1995) encontraram variações de 90 a $2110 \mu \mathrm{S}$ em méis italianos de diferentes origens florais.

Thrasyvoulou \& Manikis (1995) encontraram em amostras de méis da Grécia valores variando de 420 a $1260 \mu \mathrm{S}$ para a condutividade elétrica.

\subsubsection{Açúcares totais}

A quantidade de açúcares totais encontrada nas 36 amostras de méis analisadas variaram de 66,05 a $75 \%$, com o valor médio de $71,72 \%$ (Tabelas 2 e 3). Para os açúcares totais não existe valor estabelecido na norma vigente.

Os valores observados estão próximos aos obtidos por Komatsu (1996) que em méis de diferentes origens florais do Estado de São Paulo observou para os açúcares totais, uma variação de 67 a 88,3 \%; de Rodrigues et al. (1996), em méis de flores de eucaliptos e de flores silvestres que encontraram 73,10 e $73,12 \%$, respectivamente e de Campos (1998) que encontrou para méis de origem floral valores variando de 62 a $77,8 \%$.

\subsubsection{Açúcares redutores}

O conteúdo de açúcares redutores das 36 amostras de méis analisadas variou de 61,7 a 72,53\%, com a média de 69,20\% (Tabelas 2 e 3). A norma vigente estabelece um mínimo para açúcares redutores de $65 \%$. No trabalho em estudo observou-se que o valor médio está acima do estabelecido como limite mínimo. A Figura 12 representa a porcentagem (97\%) das amostras de méis analisadas que se enquadra dentro da norma vigente. 


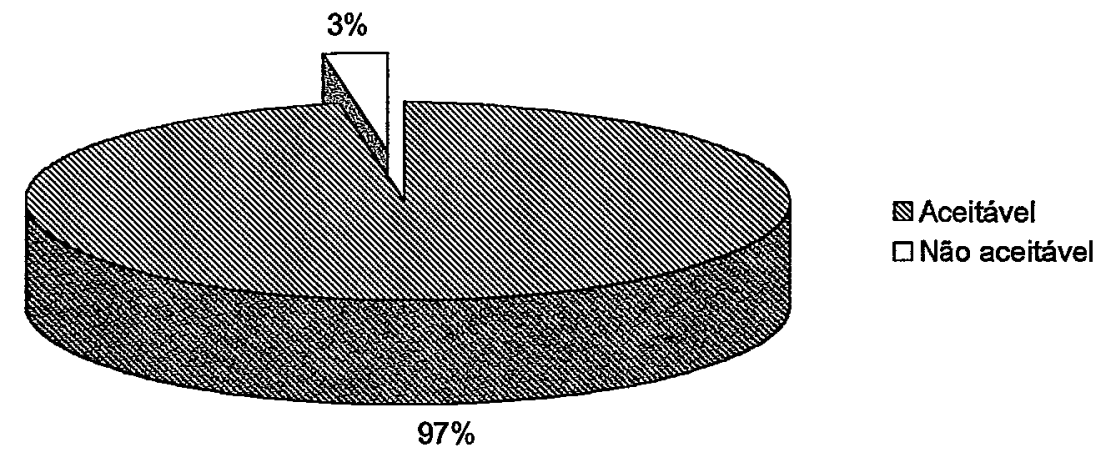

Figura 12 - Porcentagem de amostras que apresentaram açúcares redutores aceitável ou não aceitável, segundo a legislação brasileira, em 36 amostras de méis da região litoral norte do Estado da Bahia.

Os valores obtidos estão próximos aos encontrados por Komatsu (1996) que analisando amostras de méis do Estado de São Paulo encontrou valores para açúcares variando de 53,2 a 80,3\%; os de Campos (1998) que analisando méis de origem floral em Minas Gerais observou variações de 60,41 a $77,10 \%$.

Baldi Coronel et al. (1993) analisando amostras de méis da Argentina encontraram valores variando de 55 a $85 \%$ para açúcares redutores.

Os padrões europeus, conforme Bogdanov et al. (1997) aceita, para açúcares redutores dos méis de origem floral, valores maiores que $60 \%$. Para as amostras da presente pesquisa $100 \%$ delas enquadram-se nos padrões europeus.

\subsubsection{Sacarose}

Os valores de sacarose (\%) encontrados nas 36 amostras de méis analisadas variaram entre 0,38 a 7,39 com um valor médio de 2,40. (Tabelas 2 e 3). Os valores médios não excederam o valor máximo $(5 \%)$ permitido, 
entretanto, foram observadas em duas amostras (9 e 29) valores acima do permitido pela norma vigente. Na Figura 13 observa-se a porcentagem de amostras de méis $(94 \%)$ que está dentro da norma vigente.

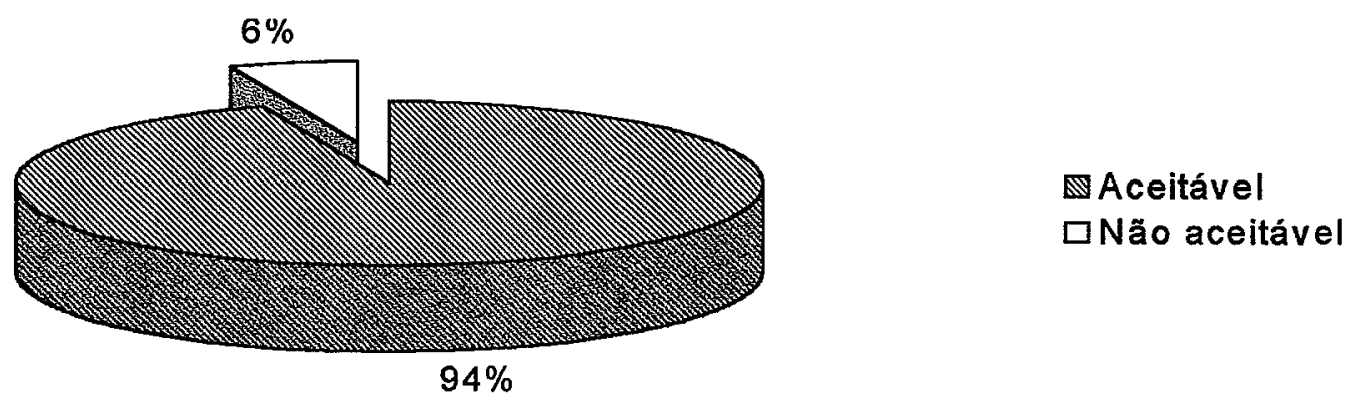

Figura 13 - Porcentagem de amostras que apresentaram sacarose aceitável ou não aceitável, segundo a legislação brasileira, em 36 amostras de méis da região litoral norte do Estado da Bahia.

Os valores observados estão próximos aos verificados por Vit et al. (1994) em méis da Venezuela que constataram para a sacarose valores variando de 0,00 a 4,73. Sporns et al. (1992), em méis do Canadá observaram, valores para a sacarose de 0,0 a $6,5 \%$.

Baldi Coronel et al. (1993) encontraram na Argentina valores para a sacarose de 1 a 13\%. Uñates et al. (1999), também na Argentina, observaram valores para a sacarose variando de 1,31 a $7,5 \%$.

Vit (1988) analisando amostras de méis da Venezuela obteve $17,4 \%$ das amostras analisadas fora das especificações estabelecidas.

Foi observado um baixo valor para a sacarose das amostras de méis de flor de eucaliptos $(0,54$ a $2,55 \%)$. 


\subsection{Análise de agrupamento}

Pela análise de agrupamento das 36 amostras de méis, chegou-se aos resultados de $99 \%$ de explicação pela análise de Cluster e de $67 \%$ de explicação pela análise de componentes principais. Os dados da análise de Cluster podem ser observados no fenograma da Figura 14.

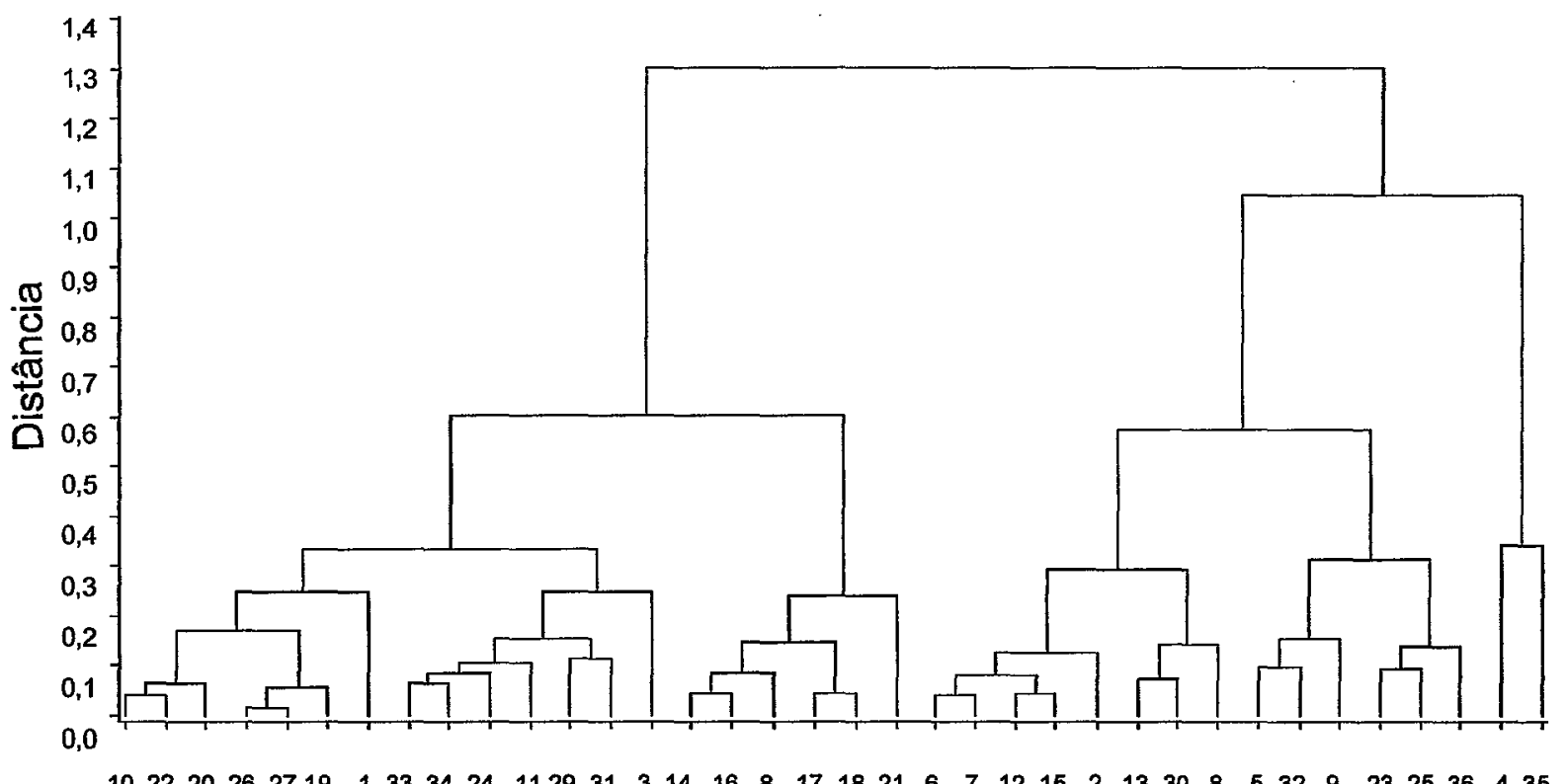

Amostras de méis analisadas

Figura 14 - Fenograma por UPGMA e distância euclidiana média de 36 amostras de méis de Apis mellifera, da região litoral norte do Estado da Bahia. 
Pelo fenograma foi possível encontrar 3 grupos, os quais podem ser identificados a seguir: no grupo 1 encontram-se 20 amostras $\left(n^{\circ} 10,22,20\right.$, $26,27,19,1,33,34,24,11,29,31,3,14,16,8,17,18,21$ ), no grupo 2,14 amostras (no $6,7,12,15,2,13,30,8,5,32,9,23,25,36)$ e no grupo 3,2 amostras(nำ04, 35), num nível de explicação de $99 \%$.

Esse resultado pode sugerir que os caracteres condutividade elétrica, o pH e a origem floral tenham tido maior influência nos agrupamentos (Tabela 2), já que Bogdanov (1999) menciona que a condutividade elétrica é considerado um bom critério de origem floral do mel, e que é influenciada pelos ácidos e o conteúdo de cinzas presentes no mesmo, pois os méis de diferentes origens florais têm valores diferentes de condutividade elétrica.

Assim, no grupo 1 foram observados os seguintes valores médios para os caracteres: condutividade elétrica $498 \mu \mathrm{S}$; $\mathrm{pH} 3,57$ e predominância de méis de origem floral da família Mimosaceae. O grupo 1 foi subdividido em 3 grupos menores (Figura 14) os quais apresentaram para a condutividade elétrica e para o $\mathrm{pH}$ os seguintes valores médios: grupo 1 (a) ( $\mathrm{n}$ - 10, 22, $20,26,27,19,01) 519 \mu \mathrm{S}$ e 3,55 , grupo 1 (b) (no $33,34,24,11,29,31,03$ ) $671 \mu \mathrm{S}$ e pH 3,66 e para grupo 1 (c) (no $14,16,28,17,18,21) 304,33 \mu \mathrm{S}$ e 3,50 , respectivamente.

Para o grupo 2 foram encontrados os valores médios de $1038 \mu \mathrm{S}$ para a condutividade elétrica e 4,0 para o $\mathrm{pH}$, sendo observado a predominância para a origem floral do gênero Eucalyptus. $O$ grupo 2 também foi subdividido (Figura 14), encontrando-se os seguintes valores médios para a condutividade elétrica e para o pH: grupo 2 (a) $\left(n^{\circ} 6,7,12,15,2,13,30,8\right)$ $1174,8 \mu \mathrm{S}$ e 4,17 e para o grupo 2 (b) (no $5,32,9,23,25,36) 902 \mu \mathrm{S}$ e 3,83 , respectivamente.

No grupo 3 (amostras 4, 35) foi encontrado para a condutividade elétrica valor médio de $1564,8 \mu \mathrm{S}$ e para o $\mathrm{pH} 3,95$ e como origem floral Mimosa 
verrucata e o tipo Asteraceae. Para esse grupo observou-se os maiores valores de proteínas $(0,971$ e 0,836$)$ (Tabela 2$)$.

Pela análise de componentes principais também separaram-se 3 grupos distintos (Figura 15 e Tabela 4), os quais são explicados em 67\% pelos 3 eixos principais $(X, Y, Z)$ (Tabela 5 ).

Para o grupo 1 tem-se 23 amostras ( $n^{\circ} 21,22,31,33,17,26,16$, $20,27,10,19,14,25,34,1,23,18,11,24,28,36,9,3)$; no grupo 2, 10 amostras $\left(n^{\circ} 32,12,7,5,15,6,2,13,830\right)$ e no grupo 3,3 amostras $\left(n^{\circ} 29\right.$, 04, 35).

Para os eixos analisados foi possível observar que o eixo $X$ foi $o$ que mais contribuiu explicando $32,2 \%$ do agrupamento; o eixo $Y$ explicou $19,7 \%$ e o eixo Z explicou 15,1\% (Tabela 5). Dos caracteres analisados para cada eixo foi possível observar que o hidroximetilfurfural (HMF), no eixo $X$, foi o que mais contribuiu para o agrupamento; no eixo $Y$ os açúcares redutores e no eixo $Z$ a acidez (Tabela 6).

Quimicamente o caracter (HMF) que mais contribuiu no eixo $X$ pode estar associado com a grande importância que tem esse componente em análise de mel, já que é um indicador de qualidade. White Júnior (1978) menciona que o HMF é formado pela reação de certos açúcares com ácidos, e que ele pode aumentar com a elevação da temperatura e o armazenamento do mel.

Os açúcares redutores foram os que mais contribuíram no eixo $\mathrm{Y}$, provavelmente devido a grande concentração encontrada no mel. White Júnior (1979) relata que os açúcares influenciam na viscosidade, higroscopicidade, granulação e valor energético do mel.

$A$ acidez foi o caracter que mais contribuiu no eixo $Z$, sendo um caracter de qualidade pois está associada à estabilidade do mel com relação ao desenvolvimento de microrganismos. 


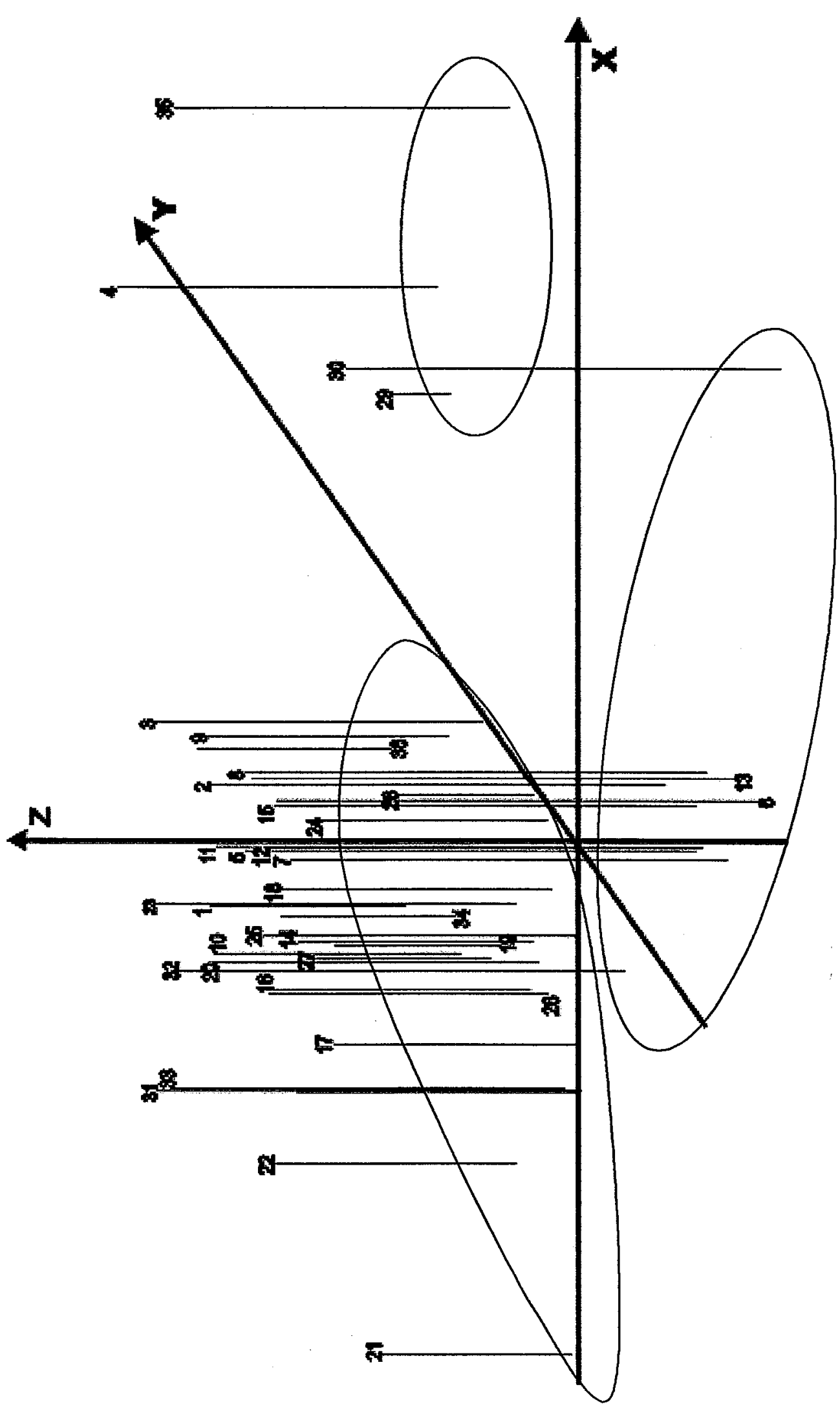

응

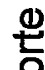

음

징

을

음

'串

Tั

(5)

【ั

$\frac{5}{2}$

$\div$

$\stackrel{0}{0}$

$\frac{\infty}{0}$

$\varepsilon$

D

은

옳

co

号

$\frac{\omega}{\sigma}$

응

등

孪

D

自 음

I

족 
Tabela 4 Valores dos eixos ortogonais

\begin{tabular}{|c|c|c|c|c|}
\hline Amostras & $x$ & $\bar{Y}$ & $\bar{Z}$ & Z corrigido \\
\hline 1 & $-0,56396$ & 0,99991 & 0,28949 & 6,28949 \\
\hline 2 & 0,40377 & $-1,59355$ & 0,95976 & 6,95976 \\
\hline 3 & 1,02777 & 1,43252 & 1,80232 & 7,80232 \\
\hline 4 & 4,78761 & 2,3257 & 2,30648 & 8,30648 \\
\hline 5 & $-0,09638$ & $-2,09436$ & 0,35204 & 6,35204 \\
\hline 6 & 0,45245 & $-3,09202$ & $-0,16995$ & 5,83005 \\
\hline 7 & $-0,14409$ & $-2,53307$ & 0,43580 & 6,43580 \\
\hline 8 & 0,68645 & $-2,16773$ & 0,35985 & 6,35985 \\
\hline 9 & 0,95238 & 2,19084 & 0,95720 & 6,95720 \\
\hline 10 & $-0,96999$ & 1,91983 & 0,23450 & 6,23450 \\
\hline 11 & $-0,01596$ & 1,62565 & 0,81307 & 6,81307 \\
\hline 12 & $-0,06292$ & $-2,11307$ & 0,09546 & 6,09546 \\
\hline 13 & 0,61155 & $-2,75383$ & 0,34038 & 6,34038 \\
\hline 14 & $-0,90248$ & 0,76446 & $-0,56581$ & 5,43419 \\
\hline 15 & 0,35632 & $-2,14771$ & $-0,11458$ & 5,88542 \\
\hline 16 & $-1,27768$ & 0,53647 & $-0,07910$ & 5,92090 \\
\hline 17 & $-1,76251$ & $-0,03203$ & $-1,01866$ & 4,98134 \\
\hline 18 & $-0,47120$ & 0,45766 & $-0,82694$ & 5,13060 \\
\hline 19 & $-0,90519$ & 1,02188 & $-0,29574$ & 5,70426 \\
\hline 20 & $-1,01654$ & 0,65718 & 0,27604 & 6,27604 \\
\hline 21 & $-4,35003$ & 0,14456 & $-2,66912$ & 3,33088 \\
\hline 22 & $-2,74498$ & 1,09796 & $-0,83019$ & 5,16910 \\
\hline 23 & $-0,53677$ & 0,22607 & 1,13074 & 7,13074 \\
\hline 24 & 0,20167 & 0,52491 & $-0,39860$ & 5,60140 \\
\hline 25 & $-0,89654$ & 0,08932 & 0,96997 & 6,96997 \\
\hline 26 & $-1,28518$ & 0,53547 & 0,81392 & 6,81392 \\
\hline 27 & $-1,00719$ & 1,44811 & $-0,38928$ & 5,61072 \\
\hline 28 & 0,59349 & 0,69242 & $-2,80897$ & 3,19103 \\
\hline 29 & 3,83654 & 2,16993 & $-5,18762$ & 0,81238 \\
\hline 30 & 4,00571 & $-3,44808$ & $-2,01025$ & 3,98975 \\
\hline 31 & $-2,10827$ & $-0,09274$ & 1,12393 & 7,12393 \\
\hline 32 & $-1,11041$ & $-0,83641$ & 0,82856 & 6,82856 \\
\hline 33 & $-2,10631$ & 0,43405 & 0,69108 & 6,69108 \\
\hline 34 & $-0,63431$ & 0,20243 & 0,63321 & 6,63321 \\
\hline 35 & 6,22050 & 1,09022 & 0,86430 & 6,86430 \\
\hline 36 & 0,83265 & 0,31706 & 1,08671 & 7,08671 \\
\hline
\end{tabular}

$\mathrm{Z}$ corrigido $=+6$ 
Tabela 5 Autovalores calculados

$X=32,2 \%$

$Y=19,7 \%$

$\mathrm{Z}=15,1 \%$

Total $=67,0 \%$

Tabela 6 Autovetores calculados para as 36 amostras de méis analisadas

\begin{tabular}{lccc}
\hline Parâmetros Analisados & $\mathrm{X}$ & Eixos & $\mathrm{Z}$ \\
\hline Cor & 0,319009 & 0,261089 & 0,025824 \\
PH & 0,142682 & $-0,452843$ & 0,291329 \\
Acidez & 0,335980 & 0,167131 & 0,513485 \\
Índice de formol & 0,133292 & 0,122306 & 0,013798 \\
Proteína & $-0,269709$ & 0,178234 & $-0,174010$ \\
Umidade & 0,135229 & 0,173863 & $-0,270354$ \\
Cinzas & 0,389245 & $-0,050491$ & $-0,432430$ \\
Condutividade elétrica & $-0,091883$ & $-0,180630$ & 0,495553 \\
HMF & 0,613511 & $-0,045891$ & 0,083537 \\
Número de diastase & $-0,165522$ & $-0,071838$ & 0,175498 \\
Açúcares totais & 0,173836 & 0,522522 & 0,115221 \\
Açúcares redutores & $-0,249457$ & 0,553539 & 0,252212 \\
Sacarose \% & $-0,000486$ & 0,000043 & $-0,000044$ \\
\hline
\end{tabular}

$11^{\circ}$ componentes nos eixos $(X, Y, Z) \square 2^{\circ}$ componentes $(X, Y, Z) \square 3^{\circ}$ componentes $(X, Y, Z)$ 


\subsection{Análises polínicas}

Em geral as análises polínicas qualitativas das 36 amostras de méis, demonstraram uma grande quantidade de grãos de pólen, sendo encontrados 27 tipos pólinicos, que contribuiram com importantes dados para a caracterização dos méis da região em estudo quanto a sua origem botânica e regional.

Com as análises quantitativas dos grãos de pólen das amostras foi possível demonstrar a importância das espécies vegetais na formação dos méis, classificando-as como pólen dominante (>45\%), pólen acessório ( 16 a $45 \%$ ), pólen isolado importante (3 a 15\%) e pólen isolado ocasional (<3\%) (Louveaux et al., 1978)(Tabela 7, Figura 15). 
Tabela 7. Espectro polínico de 36 amostras de méis de Apis mellifera, da região litoral norte do Estado da Bahia.

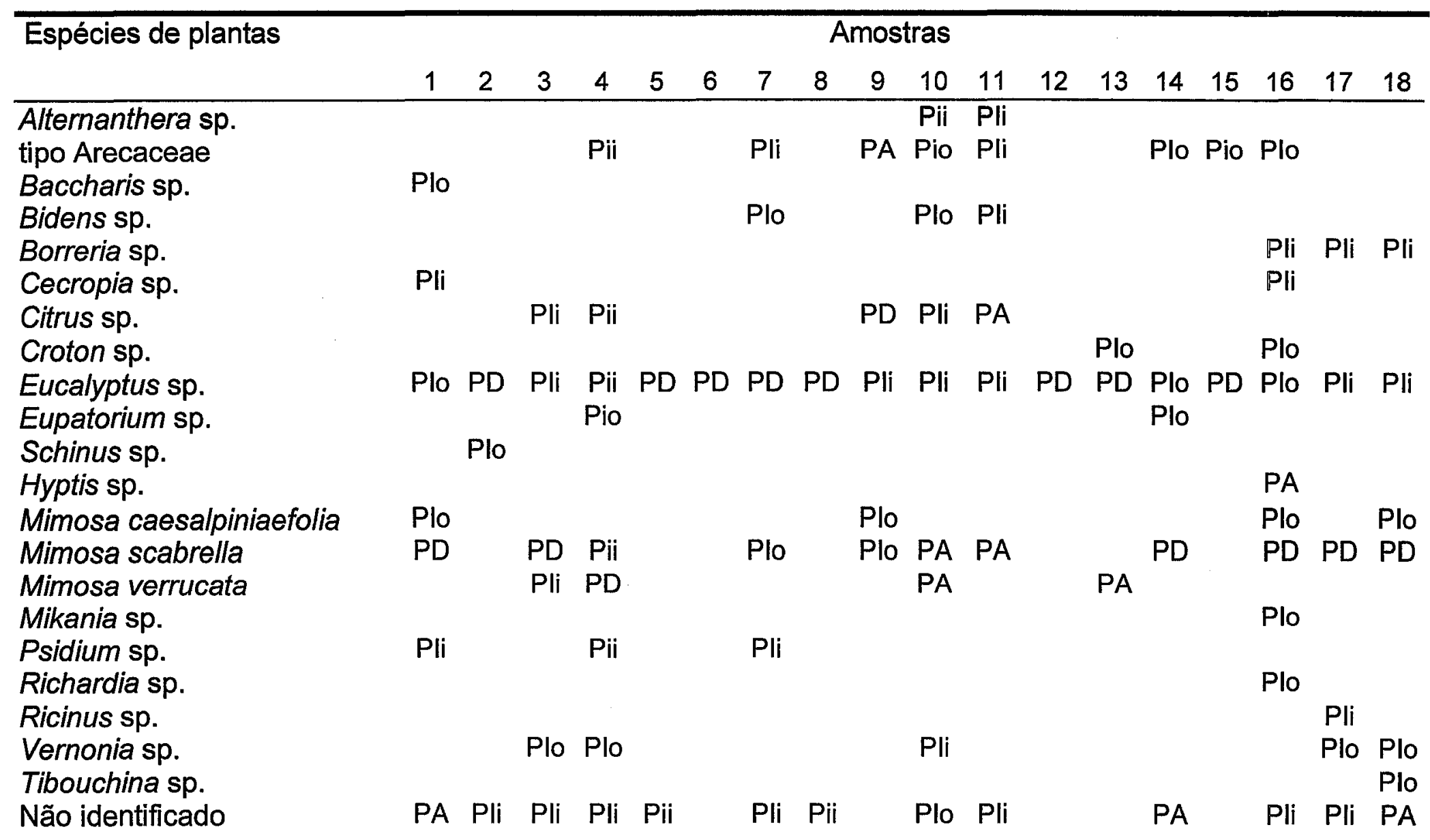


Tabela 7. Espectro polínico de 36 amostras de méis de Apis mellifera, da região litoral norte do Estado da Bahia.

Espécies de plantas

Amostras

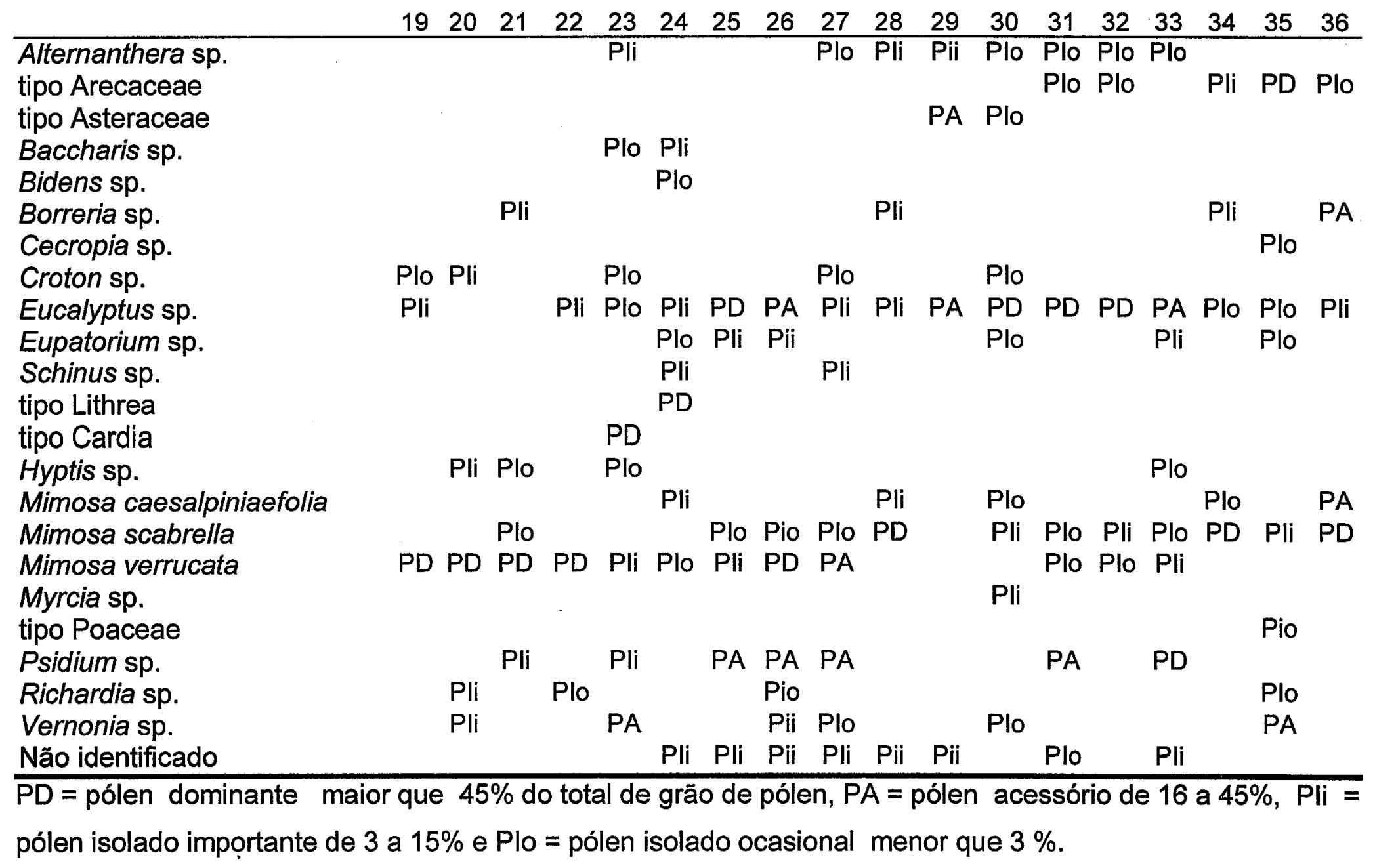




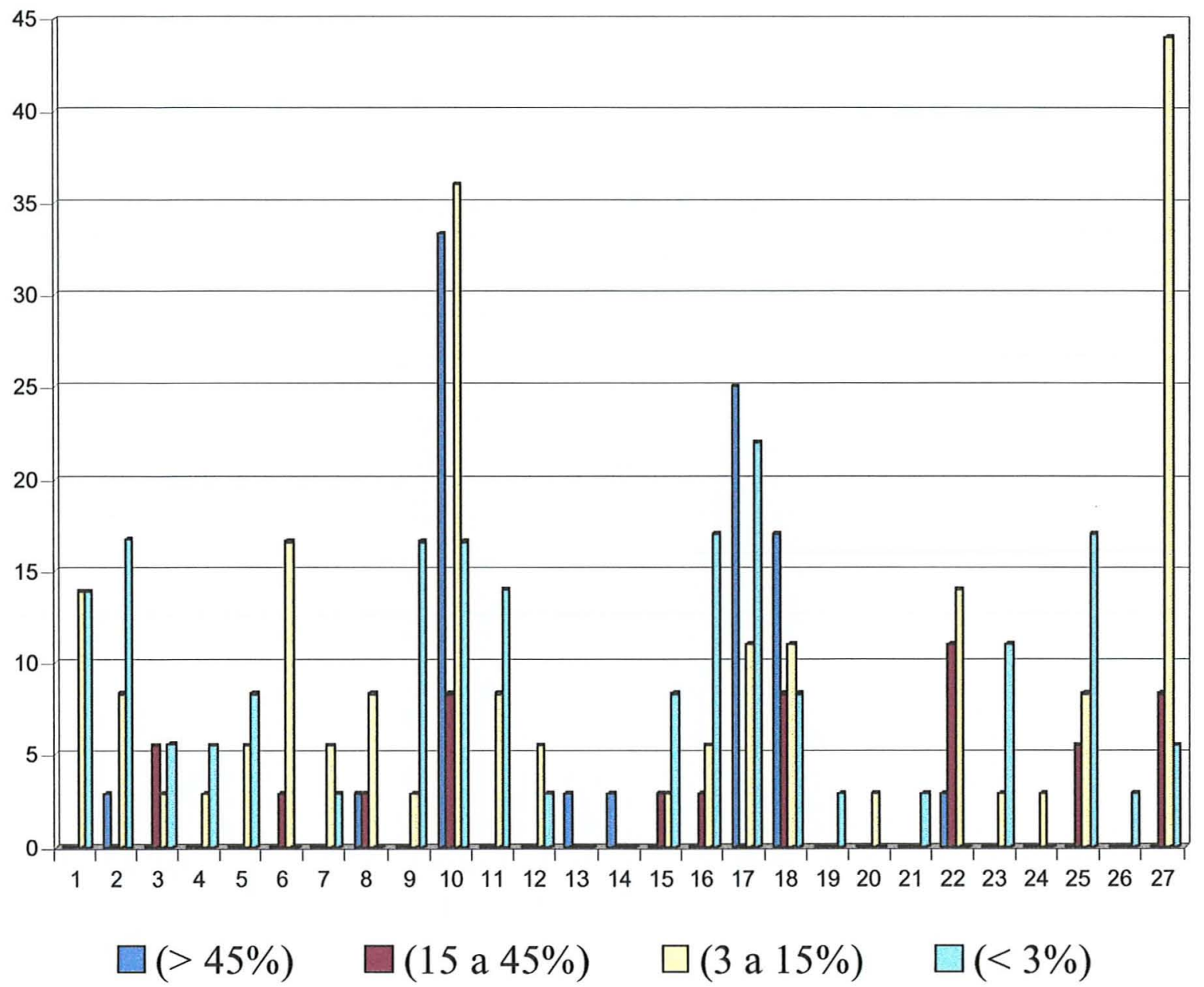

Figura 15 - Tipos polínicos de 36 amostras de méis de Apis mellifera, da região litoral norte do Estado da Bahia 1- Alternanthera sp.; 2- tipo Arecaceae; 3- tipo Asteraceae; 4- Baccharis sp.; 5- Bidens sp.; 6Borreria sp.;7- Cecropia sp.; 8- Citrus sp.; 9- Croton sp.; 10Eucalyptus sp.; 11- Eupatorium sp.; 12- Schinus sp.; 13- tipo Lithrea; 14- tipo Cardia; 15- Hyptis sp.; 16- Mimosa caesalpiniaefolia; 17- M. scabrella; 18- M. verrucata; 19- Mikania sp.; 20-Myrcia sp.; 21- tipo Poaceae; 22- Psidium sp. 23- Richardia sp 24- Ricinus sp.; 25- Vernonia sp. 26- Tibouchina sp.; 27- não identificado. 
Nas Figuras 16 e 17 observam-se as porcentagens e fotomicrografia dos tipos polínicos dominantes de 36 amostras de méis caracterizando-as pelas seguintes espécies vegetais: Eucalyptus sp. (Myrtaceae) (38\%), Mimosa scabrella Benth (Mimosaceae) (28\%), M. verrucata Benth (Mimosaceae) (19\%), tipo Arecaceae (3,1\%), Citrus sp. (Rutaceae) $(3,1 \%)$, tipo Lithrea (Anacardiaceae) $(3,1 \%)$, tipo Cardia (Boraginaceae) $(3,1 \%)$ e Psidium sp. (Myrtaceae) $(3,1 \%)$.

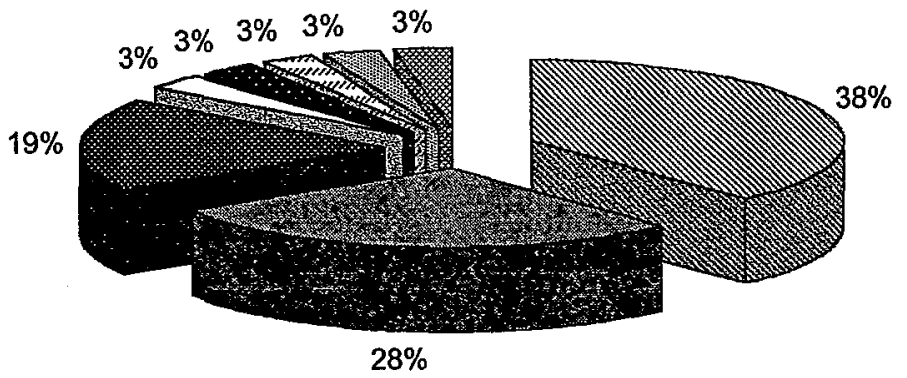

Eucalyptus sp.

Mimosa scabrella

Mimosa verrucata

$\square$ tipo Arecaceae

Citrus sp.

田Psidium sp.

图 tipo Cardia

国 tipo Lithrea

Figura 16 - Porcentagens de pólens dominantes encontrados em 36 amostras de méis de Apis mellifera, da região litoral norte do Estado da Bahia. 


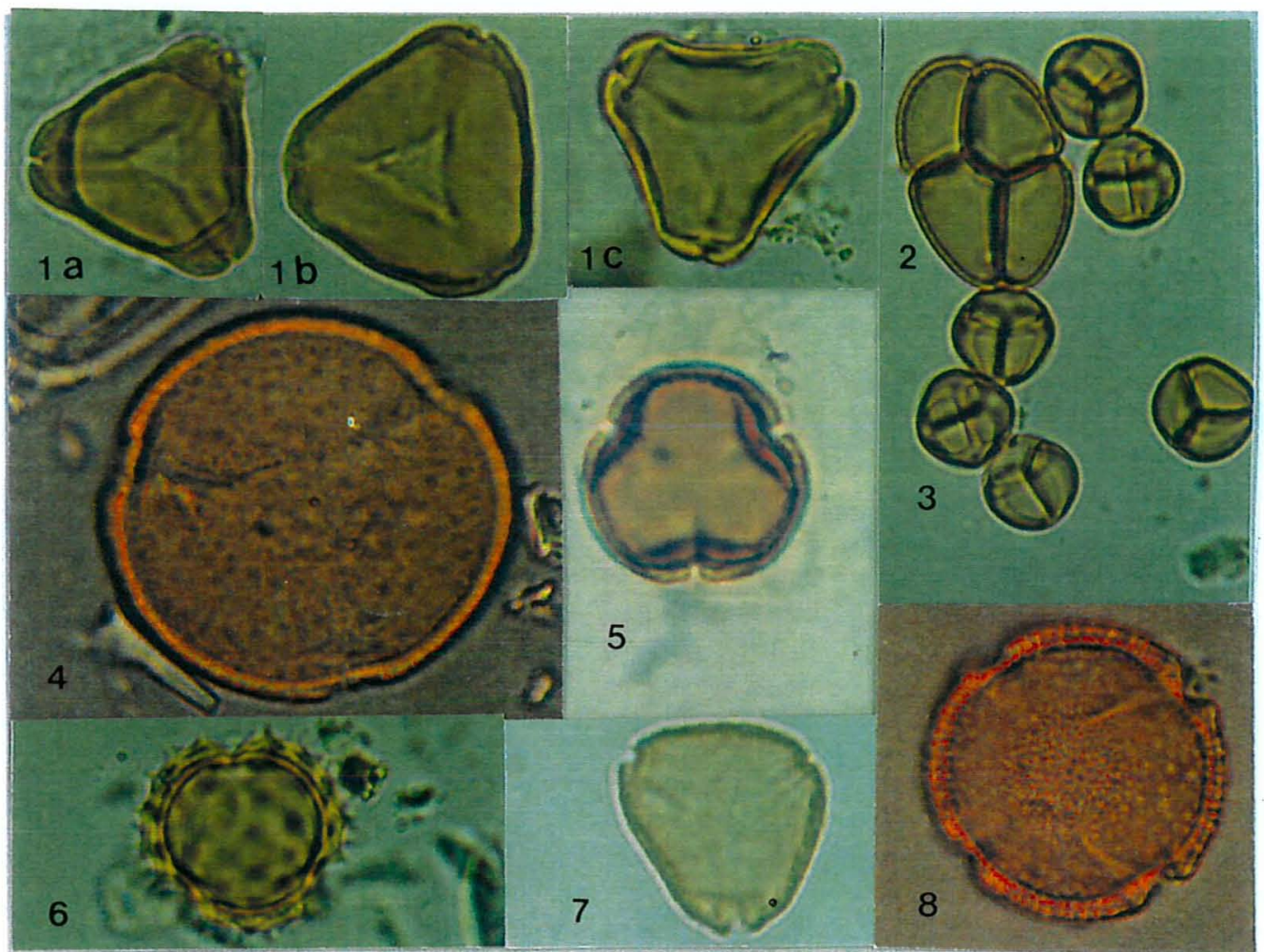

Figura 17 - Fotomicrografia dos tipos polínicos dominantes encontrados em 36 amostras de méis de Apis mellifera, da região litoral norte do Estado da Bahia (1000x):

1-Eucalyptus sp. (Myrtaceae) (a, b, c); 2- $M$. verrucata (Mimosaceae); 3- Mimosa scabrella (Mimosaceae); 4- tipo Cardia (Boraginaceae ); 5 tipo Lithrea (Anacardiaceae); 6- tipo Arecaceae; 7- Psidium sp. (Myrtaceae); 8- Citrus sp. (Rutaceae). 
Observou-se que as espécies mais freqüentes foram Eucalyptus sp., presentes em 32 das 36 (94\%) amostras, Mimosa scabrella presente em 23 das 36 (64\%) amostras e $M$. verrucata presente em 16 das 36 (44\%) amostras (Tabela 7). A grande freqüência das espécies Eucalyptus sp., Mimosa scabrella e $M$. verrucata reitera o potencial apícola destas espécies na região estudada.

Barth (1989) analisando os tipos polínicos de amostras de méis do Estado da Bahia, relata que os méis característicos desse estado são aqueles que contém, como pólen dominante ou acessório, grãos das mimosáceas: Mimosa scabrella, M. verrucata, M. caesalpiniaefolia e Acacia sp., mencionando a espécie Eucalyptus sp. como pólen acessório. Barth (1970a) cita que o pólen de Eucalyptus sp. é característico nos méis do Brasil meridional.

A grande utilização das diferentes espécies de Eucalyptus para reflorestamento no Estado da Bahia justifica o grande aumento da participação desse tipo polínico nas amostras de méis analisadas.

Através da análise quantitativa foi possível observar uma menor freqüência dos pólens acessórios se comparados com os pólens dominantes (Tabela 7, Figura 15 ), entretanto, Barth (1970b) relata que os méis com pólens acessórios são mais freqüentes que os com pólen dominante, devido ao fato de que a apicultura brasileira é realizada de maneira rudimentar. A autora salienta a importância do pólen acessório e do dominante quanto à quantidade de néctar fornecida, ao contrário do pólen isolado.

Com relação ao tipo de pólen acessório foram observados dois tipos de méis: um que além do pólen acessório apresentou também pólen dominante (amostras 1, 9, 13, 14, 16, 18, 23, 25, 26, 31, 33, 35, 36) e o outro que apresentou uma ou mais espécies de pólen acessório sem presença de pólen dominante (amostra 10, 11, 27, 29) (Tabela 7). Para o tipo polínico acessório foram encontrados as seguintes espécies vegetais: tipo Asteraceae; Borreria sp.; Citrus sp.; Eucalyptus sp.; Hyptis sp.; Mimosa caesalpiniaefolia; $M$. scabrella; M. verrucata; Psidium sp. e Vernonia sp. 
As análises polínicas das amostras estudadas mostraram uma grande participação dos pólens isolados importantes e ocasionais, sendo encontrados em quase todas as amostras (Tabela 7, Figura 15). Barth (1989) menciona que quanto à quantidade de néctar fornecido, estas espécies têm pouca importância, entretanto, quanto à origem e procedência geográfica das amostras podem ser significativos.

Uma identificação completa dos tipos polínicos, exceto para as espécies mais conhecidas, torna-se difícil pela falta de conhecimento polínico da vegetação melífera da região em estudo. Barth (1970b) relata que por este motivo recorre-se ao "tipo polínico" o qual engloba todas as espécies que possuem grãos de pólen iguais ou muito semelhantes, pertencendo ou não, à espécie do mesmo gênero. 


\section{CONCLUSÃO}

As características dos méis do presente estudo são estabelecidas pelas seguintes faixas de variações: umidade de 17,66 a $22,9 \%$; cor escuro a extra branco; proteína de 0.056 a $0,971 \%$; pH de 3,37 a 4,46; acidez de 13 a 43meq/kg; índice de formol de 1,67 a 29ml/kg; número de diastase de 16,66 a 62,81 Gothe; hidroximetilfurfural de 1,5 a $136 \mathrm{mg} / \mathrm{kg}$; cinzas de 0,094 a 0,668\%; condutividade elétrica de 271,67 a $1634 \mu \mathrm{S}$; açúcares totais de 66,05 a $75,52 \%$; açúcares redutores de 61,7 a $72,53 \%$; sacarose de 0.38 a $7,39 \%$.

As porcentagens das amostras para cada parâmetro físicoquímico que se enquadram nas especificações permitidas pela legislação brasileira são: umidade $91,66 \%$; cor $100 \%$; proteína $78 \%$; $\mathrm{pH} 100 \%$; acidez $97 \%$; índice de formol $78 \%$; condutividade elétrica $61 \%$; cinzas $94 \%$; número de diastase $100 \%$; hidroximetilfurfural $84 \%$; açúcares redutores $97 \%$; sacarose $94 \%$.

Os méis da região litoral norte do Estado da Bahia contém como pólens dominantes Eucalyptus sp., Mimosa scabrella e M. verrucata, principalmente.

O hidroximetilfurfural e os açúcares redutores foram os caracteres que mais influenciaram para o agrupamento das amostras.

Existem dois grupos de espécies vegetais que predominam na região como planta apícola. 


\section{REFERÊNCIAS BIBLIOGRÁFICAS}

ABDELNUR, P. A.; FURANI, S. R. C.; BATISTUTI, J. P. et al. Efeito do tempo de armazenamento e do tipo de embalagem nas características físicoquímico de méis. In: CONGRESSO BRASILEIRO DE APICULTURA, 12, Salvador, 1998. Anais. Salvador: Confederação Brasileira de Apicultura,1998. p.203.

ACCORTI, M.; PIAZZA, M.G.; ODDO, L. P. Electrical condutivity and ash content of honey. Apicoltore Modero, v. 77, n. 4, p. 165-167, 1986. Apud Apicultural Abstracts, v.38, n.2, p.167, 1987.

AGANIN, A. F. Electrical condutivity of several unifloral honeys. Trudy Saratovskogo Zootekhnicheskogo Inatituta, v. 21, p. 137-144, 1971. Apud Apicultural Abstracts, 1973. (Resumo).

Al-KHALIFA, A. S.; AL-ARIFY, I. A. Physicochemical characteristics and pollen spectrum of some Saudi honeys. Food Chemistry, v. 67, n. 1, p. 21-25, 1999.

AMARAL, A. D.; IMPERATRIZ-FONSECA, V. L.; GIOVANNINI, A. K. et al. Estudo comparativo entre amostras de méis com origem floral determinada; análise do teor de proteínas, lipídios e carboidratos totais. In: CONGRESSO BRASILEIRO DE APICULTURA, 7, Salvador, 1986. Anais. Salvador: Confederação Brasileira de Apicultura, 1986. p.60. 
ANDRADE, P. B.; AMARAL, M. T.; ISABEL, P. et al. Physicochemical attributes and pollen spectrum of Portuguese heather honeys. Food Chemistry, v. 66, n. 4 , p. 503-510, 1999.

ANUÁRIO ESTATÍSTICO DO BRASIL-1995, v.1, p.20. 1995.

ARCHENTI, A. Chemical composition of honeys from Chubut province (Argentina). Revista de Ciências Agrárias, v. 5, n. 1/4, p. 12-28, 1984.

ARCHENTI, A.; DASSO, I. Composicion quimica de mieles de la provincia de Chubut (Argentina). Alimentacion Latinoamericana, n.138, p.11-19, 1983.

ATAGO Co. Refractômetro para mel. Abelhas, v. 31, n. 362/363, p.9, 11-12, 41,44, 1988. /Resumo em CAB Abstracts on CD-ROM, 1987-89.

AZEREDO, M. A. A.; AZEREDO, L. da C. Características físico-químicas dos méis do município de São Fidélis-RJ. Ciência e Tecnologia de Alimento, v. 19 , n. 1, p. 3-7, 1999.

BALDI, B.; DALL'OGLLIO, A. M.; LEZCANO, S. Caracterización físico químico de las mieles de la Provincia de Entre Rios. In: CONGRESSO IBERO LATINOAMERICANO DE APICULTURA. 5 Uruguai, 1996. Anais Uruguai: 1986, p.218-222.

BALDI, B.; DALL'OGLLIO, A. M.; LEZCANO, S. Caracterización físico químico de las mieles de la Provincia de Entre Rios. Alimentación Latinoamericana, n.39, p.39-44,1993. 
BALENOVIC, J.; PERKCVAC, M.; PAPIC, J. Hydroxymethylfurfural content and amylase activity in honey. Prehrambeno Tehnoloska Revija, v.26, n.4, p.143-6, 1988.

BARTH, M. O. O pólen no mel brasileiro. Rio de Janeiro: Gráfica Luxor, 1989. 152p.

BARTH, O. M. Análise microscópica de algumas amostras de mel; 1 Pólen Dominante. Anais Academia Brasileira de Ciências, v. 42, n.2, p.351$366, .1970 a$.

BARTH, O. M. Análise microscópica de algumas amostras de mel; 2 Pólen Acessório. Anais Academia Brasileira de Ciências. v. 42, n.3, p.571-590, $1970 b$.

BARTH, O. M. Análise microscópica de algumas amostras de mel; 3 Pólen isolado. Anais Academia Brasileira de Ciências, v. 42, n. 4, p.748-772, 1970c.

BARTH, O. M. Análise microscópica de algumas amostras de mel; 6, Espectro polinico de algumas amostras de mel dos Estados da Bahia e do Ceará. Revista Brasileira de Biologia, v. 31, n. 4, p. 431-434, 1971.

BARTH, O. M. Pollen in monofloral honey from Brazil. Journal of Apicultural Research, v. 29, p.89-94, 1990.

BASTOS, D.H.M.; SILVA, J.R. Análise de méis produzidos na região Bragantina. LECTA, v. 12, n. 2, p. 121-34, 1994. 
BASTOS, E. M. A. F. Grão de pólen e estruturas secretoras de plantas como indicadores da origem botânica do mel e da própolis. In: CONGRESSO BRASILEIRO DE APICULTURA, 12 Salvador, 1998 .Anais. Salvador: Confederação Brasileira de Apicultura, 1998, p.71-72.

BASTOS, E. M.; BRANDÃO, M.; SILVEIRA, F. R. C. da. Espectro polínico dos méis produzidos no parque da Serra do Caraça - MG. Daphne, v. 5,n. 1, p. 40-45, 1995.

BATH, P. K.; SINGH, N. A comparison between Helianthus annuus and Eucalyptus lanceolatus honeys. Food Chemistry, v. 67, n. 4, p. 389-397, 1999.

BOGDANOV, S. Honey quality and international regulatory standards: review by the international honey commission. Bee World, v. 80 , n. 2, p. 61-69, 1999.

BOGDANOV, S.; MARTIN, P.; LULLMANN, C. Harmonized methods of the european honey commission. Apidologie, Extra. issue p. 1-59, 1997

BONVEHÍ, J. S.; COLL, F. V. Characterization of citrus honey (Citrus spp.) produced in Spain. Journal of Agricultural Food Chemistes, v. 43, p. 2053-2057, 1995.

BRANDÃO, M.; BASTOS, E. M. Espectro polínico dos méis produzidos na Serra da Piedade, município de Caeté, MG. Daphne, v. 5,n. 4, p. 10-14, 1995. 
BRASIL. Leis, decretos, etc. Decreto no 30.691, de 08 de setembro 1997. Diário Oficial, de 08 de set.. 1997. Seção 1, p.19696-19697. Aprova as Normas o Regulamento Técnico para Fixação de Identidade e qualidade do mel.

BRICE, B. A.; TURNER, A.; WHITE, J. W. Glass color standardds for extracted honey. Journal of the Association of Official Agricultural Chemistes, v.11, p.919-937,1956.

BUTTA, A.; CASERIO, G.; BIZZOZERO, M. et al. Indagine sulla qualità merceologica e sulle carattrristiche microbiologiche di mieli in commericio. Industriw Alimentari, v. 22, n. 210, p.838-44, 1983.

CAMPOS, G. Melato no mel e sua determinação através de diferentes metodoilogias. Belo Horizonte-MG, 1998. 178p. Tese (Doutorado) - Escola de Veterinária - Universidade Federal de Minas Gerais.

CARVALHO, C. A. L. de; MARCHINI, L. C.; SODRÉ, G. da S. et. al. Análises de amostras de méis provenientes do recôncavo da Bahia. ENCONTRO SOBRE ABELHAS. 4 Ribeirão Preto, 2000.Ribeirão Preto, 2000, p.352.

CARVALHO, C. A. L. de; MARCHINI, L. C.; TEIXEIRA, G.M. et al. Características físico-química de amostras de méis da Bahia. In: CONGRESSO BRASILEIRO DE APICULTURA, 12, Salvador, 1998. Anais. Salvador: Confederação Brasileira de Apicultura, 1998, p.200.

CARVALHO, C. A. L.; MARCHINI, L. C. Tipos polínicos coletados por Nannotrigona testaceicornis e Tetragonisca angustula (Hymenoptera, Apidae, Meliponinae). Scientia Agricola, v.56, n.3, p.717-722, jul./set. 1999. 
CORNEJO, L. G. Tecnologia de miel. In: SEEMANN, P.; NEIRA, M., (Ed.) Tecnologia de la produccion apicola. Valdivia: Universidad Austral de Chile, Facultad de Ciencias Agrarias, 1988. p.145-171.

CORTOPASSI-LAURINO, M.; GELLI, D. S. Analyse pollinique, propriétés physico-chimiques et action antibactérienne des miels d'abeilles africanisées Apis mellifera et de Méliponinés du Brésil. Apidologie, v. 22, p. $61-73,1991$.

COSTA, L. S. M.; AlBUQUERQUE, M. L. S.; TURGO, L. C. et al. Determination of non-volatile compounds of different botanical origin brazilian honeys. Food Chemistry, v. 65, p. 347-352, 1999.

CRANE, E. Bees and beekeeping-science, practice and world resources. Neinemann Newnes, Eva Crane 1990.614 p.

CRECENTE, R. P.; LATORRE, C. H. Pattern recognition analysis applied to classification of honeys from two geographic origins. Journal of Agricultural Food Chemistes, v. 41, p. 560-564, 1993.

DAYRELL, I. O.; VITAL, N. C. Comparação entre dois métodos oficiais para determinação de hidroximetilfurfural (HMF) em mel brasileiro. Ciência e Tecnologia de Alimento, v. 11, n. 1, p.137-141, 1991.

DURKEE, L.H. A Pollen profile from woden bog in North-Central lowa. Ecology, v. 52, n. 5, p.837-844. 1971.

EL-SHERBINY, G. A.; RIZK, S.S.; EL-ASHWAH, F A. Chemical composition of citrus honey producede in A. R. E. Agricultural Research Review, v. 58, n. 3, p. 289-97, 1980. 
ESCOBAR-MARTÍNEZ, C. A.; GIMÉNEZMEZA, G. G. \& MENDOZA, Q. M. R. Mieles de abejas de flor paraguaya: composicion, tipificacion y norma lizacion. San Lorenzo: Ministerio de Agricultura y Ganaderia; Universidad Nacional de Asuncion; asociacion Suiza para el Desarrollo y la Cooperacion, 1992. 31 p.

FARAJI-HAREMI, R.; HOSSEINI, Z. Chemical composition of honeys from Fars and Kohkiluyeh provinces of Iran. Iran Agricultural Research, v. 6, n. 2. p.73-81, 1987. Resumo em CAB Abstracts on CD-ROM, 1990-91/

FERNÁNDEZ-SALGUERO, J.; GÓMEZ, R. Aportación al estudio de los alimentos españoles de humedad baja. Alimentaria, v. 29, n. 229, p.83-5, Jan./Fev. 1992.

FLECHTMANN, C. H. W.; CALDAS FILHO, C. F.; AMARAL, E. et al. Análise de méis do estado de São Paulo. Boletim de Indústria Animal, v. 21, p. 6573, 1963.

FREITAS, B. M. Potencial de caatinga para a produção de pólen e néctar para a exploração apícola. Fortaleza, 1991. 140p. Dissertação (Mestrado)Universidade Federal do Ceará.

FRÍAS, I.; HARDISSON, A. Estudio de los parámetros analíticos de interés en la miel. II. Azúcares, cenizas y contenido mineral y color. Alimentaria, v. 28, n. 235, p.41-3, 1992.

GOMEZ, M. E. M.; HERNANDEZ, E. G.; GOMEZ, J. Y M. et al. Physicochemical analysis of Spanish commercial Eucaliptus honeys. Journal of Apicultural Research, v. 32, n. 3/4, p.121-6, 1993. 
GONZALES, A. P.; BURIN, L.; BUERA, M. del P. Color changes during storage of honeys in relation to their composition and initial color. Food Research International, v. 32, p. 185-191, 1999.

HANKIN, L. Analysis of honey. Bulletin, Connecticut Agricultural Experiment Station, n. 847, 1987, 6p. Apud Apicultural Abstracts, v. 41, n. 2-4, p.165, 1990. (Resumo).

HASE, W.; AINDA, Y. Studies on the quality of hney on the market in Japan with special reference to its relation to the "Codex Alimentarius". In: INTERNATIONAL CONGRESS OF APICULTURE, 30., Nagoya, 1985. Apimondia, p. 338-42, 1986. Apud Apicultural Abstracts, v.39, n.1, p.77, 1988. (Resumo).

HORN, H.; alunos da disciplina Análise de Mel da Universidade de Hoheinheim, Alemanha. Méis brasileiros: resultados de análise físico-químico e palinológicas. In: CONGRESSO BRASILEIRO DE APICULTURA, 11, Piauí, 1996. Anais. Piauí: Confederação Brasileira de Apicultura, 1996, p.403-429.

HOWER, F.N. Plantas melíferas. Barcelona: Reverté, 1953. 35p.

HUIDOBRO, J. F.; SIMAL, J. Determination of sugars in honey. Anales de Bromatologia, v. 36, n. 2 p. 247-264, 1984.

IBRAHIM, S.H.; SOLIMAN, N.Z.; WISSA, H. Studies on the properties of the major Egyptian honey types and honey ripening. Agricultural Research Review, v. 55, n. 1, p.125-129, 1977. Apud Apicultural Abstracts, v. 32, n. 1, p.52-53, 1981. (Resumo). 
IMPERATRIZ-FONSECA, V. L.; GIOVANNINI, A. GUIBI, L. S. et al. Preliminary study of Brasilian honeys. In: INTERNATIONAL APICULTURAL CONGRESSO, 30 Nogoya, 1987, p. 312.

ISSA, M. R. JONG, D. de; HORN, H. Caracteristicas fisico-química de amostras de méis de méis normais, aquecidos e misrurados. In: CONGRESSO BRASILEIRO DE APICULTURA. 12 Salvador, 1998. Anais Salvador: Confederação Brasileira de Apicultura, 1998, p.209.

IWAMA, S.; MELHEM, T. S. The pollen spectrum of the honey of Tetragonisca angustula angustula Latrelle (Apidae, Meliponinae). Apidologie, v. 10, n. 3 , p.275-295, 1979.

KOMATSU, S. S. Caracterização físico-química de méis de Apis mellifera L., 1758 (HYMENOPTERA: APIDAE) de diferentes municípios de São Paulo. Piracicaba-SP, 1996. 89p. Tese (Doutorado) - Escola Superior de Agricultura "Luíz de Queiroz", Universidade de São Paulo.

KOMATSU, S. S.; MARCHINI, L. C. Teores de açúcares redutores e sacarose de amostras de méis de flores silvestres produzidos por Apis mellifera no Estado de São Paulo. In: CONGRESSO BRASILEIRO DE APICULTURA, 12 Salvador, 1998. Anais Salvador: Confederação Brasileira de Apicultura, 1998. p.344

KOMATSU, S.S.; MARCHINI, L.C. Índice de diastase e hidroximetilfurfural em amostras de méis de flores de laranjeira produzidos por Apis mellifera no Estado de São Paulo. In: CONGRESSO IBERO LATINOAMERICANO DE APICULTURA. 5 Uruguai, 1996. p. 225. 
LASCEVE, G.; GONNET, M. Analyse por radioactivation du contenu mineral d'un miel. Possibilité de preciser son origine. Apidologie, v. 5, n. 3, p.201223, 1974.

LOUVEAUX, J. MAURIZIO, A. VORWOHL, G. Methods of Melissopalinology. Bee World, v. 59, n. 4, p.139-157, 1978.

LOWER, E. S. Honey its properties and uses Part I British Food Journal, v.98, n.939, p.84-7, Jul/ Aug. 1987.

MAGALHÃES, E. de O.; SICUPIRA, P. R. TERRA, P. S. Levantamento preliminar da flora apícola Sul da Bahia. In: CONGRESSO BRASILEIRO DE APICULTURA. 11 Piauí: Confederação Brasileira de Apicultura, 1996. Anais. Piauí, 1986. p.326.

MARCHINI, L. C.; CARVALHO, C. A. L. de; ROS, P. B. Tipos polínicos coletados por Partamona cuoira (HYMENOPTERA, APIDAE, MELIPONINAE ) In: INTERNATIONAL APICULTURAL CONGRESS, 35 (APIMONDIA) Belgium, 1997. Anais. Belgium, 1997, p.290.

MARCHINI, L. C.; CARVALHO, C. A. L.;ALVES, R. M. de O. et al. Características físico-química de amostras de méis da abelha uruçu. In: CONGRESSO BRASILEIRO DE APICULTURA. 12 Salvador, 1998. Anais. Salvador: Confederação Brasileira de Apicultura, 1998. p.201.

MARCHINI, L. C.; RODRIGUES, A. C. L.; MORETI, A. C. de C. C. Características qualitativas de méis que passaram por diferentes tipos de descristalização. In: CONGRESSO BRASILEIRO DE APICULTURA, 12 Piauí, 1996. Anais. Piauí p.348. 
MARTINEZ, G. M. E.; GUERRA, H. E.; MONTILLA, G. S. et al. Physicochemical analysis of Spanish commercial Eucalyptus honey Journal of Apicultural Research, v. 32, n. 3-4, p. 121-126, 1993.

McGregor, S. E. La apicultura en los Estados Unidos, México: Editora. Limusa, 1979. 93p.

MENDES, E.; PROENÇA, E. B.; FERREIRA, I. M. P. L. V. O. et al. Quality evaluation of portuguese honey. Carbohydrate Polymers, v. 37, n. 3, p. 219-223, 1998.

MESALLAN, A. S.; EL-SHAARAWY, M. I. Quality attributes of honey in Saudi Arabia. Food Chemistry, v. 25, n. 1, p.1-11, 1987.

MORAES, R. M. de; TEIXEIRA, E. W. Análise de mel (Manual técnico). Pindamonhangaba:SN, 1998. 41p.

MORAES, R.M. de.; BENEVIDES, L.H.T.S.; MENEZES, A. de. Et al. A desumidificação do mel no Brasil. Apicultura \& Polinização, n. 31, p.27-9, 1989.

MORETI, A. C. de C. C.; CARVALHO, C. A. L. de; MARCHINI, L. C. et al. Espectro polínico de amostras de méis de Apis mellifera. In: CONGRESSO BRASILEIRO DE APICULTURA, 12 Salvador, 1998. Anais Salvador: Confederação Brasileira de Apicultura, 1998 p.189.

MORETI, A. C. de C. C.; MARCHINI, L. C.: OLIVEIRA, P. C. F. Principais tipos polínicos observados em amostras de mel silvestre, produzido por abelhas (Apis mellifera L) no estado de São Paulo. In: ENCONTRO SOBRE ABELHAS, 14 Ribeirão Preto, 2000. Ribeirão Preto, 2000, p. 345. 
NATARAJAN, R.; YESUVADIAN, M. S. Project report for a honey concentration equipament. Indian Honey, v. 1, n. 1 p. 15-21, 1978. /Resumo em CAB Abstracts on CD-ROM, 1984-86/

NELSON, N. A photometric adaptation of the Somogy method for the determination of glucose. Journal of Biolgical Chemistry, v. 153, 375p. 1944.

OLEK, A. STEINKRAUS, K. H.; MATTICHK, L. R. et al. Carbohydrate composition of two nepalese honeys produced by Apis lobariosa and Apis cerana. Journal of Apicultural Research, v. 26, n. 3, p.203-4, 1987.

ORTIZ, V. A. The ash content of 69 honey samples from La Alcarria and neighbouring areas, collected in the period 1985-87. Cuadernos de Apicultura, n. 5, p.8-9, 1988. Apud Apicultural Abstracts, v. 40, n. 4, p.360, 1989. (Resumo).

PAMPLONA, B. C. Exame dos elementos químicos inorgânicos encontrados em méis brasileiros de Apis mellifera e suas relações físico-biológicas. São Paulo, 1989. 131p. Dissertação (Mestrado) - Instituto de Biociências, Universidade de São Paulo.

PENG, Z. F.; PAN, J. G. Protein content in honey and its effects on precipitation of beverage. Food Science, v. 12, p. 6-8, 1994.

PERÉZ, C.; CONCHELLO, P.; ARIÑO, A. et al. Estudio de algunos parametros fisico-quimicos en mieles monoflorales de Zaragoza. Alimentaria, v. 27, n. 213, p.59-61 Jun. 1990. 
PERSANO-ODDO, L. P.; PIAZZA, MG; SABATINI, AG. Et al. Characterization of unifloral honeys. Apidologie, v. 26, p. 453-465, 1995.

PERSANO-ODDO, P. L.; BALDI, E. ACCORTI, M. Diastatic activity in some unifloral honey. Apidologie, v. 21, p. 17-24. 1990.

PHADKE, R. P. Studies on Indian honeys. 1. Proximate composition na physico-chemical characteristics of Indian multifloral apiary honeys from Apis índica bee. Indian Bee Journal, v. 29, p. 14-26, 1967. /Resumo 478 em Apicultural Abstracts, 1972.

PREGNOLATO, W. Coord. Normas analíticas do Instituto Adolfo Lutz, v. 1. Métodos químicos e físicos para analise de alimentos coordenados por Waldomiro Pregnolato e Neus Pascuet Pregnolato. 3 ed. São Paulo: Instituto Adolfo Lutz, 533p. 1985.

REIO, L.; ENGLUND, L. Honey and its composition. Var Föda, v. 37, n. 2, p. 42-62, 1985. /Resumo em CAB Abstracts on CD-ROM, 1987-89.

RENDÓN, S. R. Estudio de la composicion fisico-quimica de las mieles extremenas y extranjeras. In: CONGRESSO IBERO LATINOAMERICANO DE APICULTURA, 5. Uruguai, 1996. Anais. Uruguai, 1996. p.174-83.

RODRIGUES, A. C. L.; MARCHINI, L. C.; HADDAD, M. de L. Características qualitativas das partes cristalizadas e de sobrenadante e diferentes méis. CONGRESSO BRASILEIRO DE APICULTURA, 11. Piaui,1996 Anais. Piauí: Confederação Brasileira de Apicultura, 1996, p.349. 
SALINAS, F.; ESOINOSA-MANSILLA, A. BERZAS-VEVADO, J.J. Flowinjection determination of HMF in honey by Winkler method. Fresenius, Journal of Analytical Chemistry, v. 340, n. 4, p.250-2, 1991.

SANCHO, M. T.; MUNIATEGUI, S.; HUIDOBRO, J. F. et al. Aging of honey. Journal of Agricultural and Food Chemistry, v. 40, p. 134-138, 1992.

SANCHO, M. T.; MUNIATEGUI, S.; HUIDOBRO, J. F. et al. Provincial classification of bosque country (northern Spain) honeys by their chemical composition. Journal of Apicultural Research, v. 30, n. 3/4, p. 168-172, 1991.

SANTOS, C. F. O. Análise polínica de alguns méis do Estado de São Paulo. In: Congresso Brasileiro de Apicultura, 3. Piracicaba, 1974. Anais Piracicaba ESALQ, 1974. p. 273-278.

SANTOS, C. F. O. Avaliação do período de florescimento das plantas apícola no áno de 1960, através do pólen contidos nos méis e dos coletados pelas abelhas (Apis mellifera) Anais Escola Superior de Agricultura "Luiz de Queiroz. V. 21, 253-264. 1964

SANTOS, C. F. O. Morfologia e valor taxonômico do pólen das principais plantas apícolas Piracicaba, 1961. 92p. Tese (Mestrado). Escola Superior de Agricultura "Luiz de Queiroz", Universidade de São Paulo.

SAS INSTITUTE. SAS/STAT:user's guide - version 6. 4. Ed. Cary, 1990.

SCHADE, J. W.; MARSH, G.; L.ECKERT, J. E. Diastase activity and hydroxmethylfurfural in honey and their influence in detecting heat alteratioin. Food Research, v. 23, p. 446-463, 1958. 
SEEMANN, P.; NEIRA, M. Tecnología de la producción apícola. Valdivia: Universidad Austral de Chile Facultad de Ciencias Agrarias Empaste, 1988. 202p.

SEIJO, M.C.; AIRA, M.J.; IGLESIAS, I. et al. Palynological characterization of honey from La Coruña province (NW Spain). Journal of Apicultural Research, v. 31, n. 3/4, p.149-155, 1992.

SIMAL, J.; HUIDOBRO, J. Parámetros de calidade de la miel III. Acidez (pH, libre, lactónica \& total) e índice de formol. Offarm, v. 3 n. 9, p. 532, 1984.

SMITH, F. G. Deterioration of the colour of honey. Journal of Apicultural Research, v. 6, n. 2, p.95-98, 1967.

SOLOVEVE, T. Ya. Determination of adulteration of honey on the basis of characteristics of honeys from single or multiple flower sources. Sb. Trud. Leningr. Inst. Sov. Torgovli, v.23, p.9-13, 1964. Apud Apicultural Abstracts, v. 22, n. 1, p.52-3, 1971 (Resumo).

SPETTOLI, P.; CECCHINI, A.; MATCOVICH, P. Indigine sulle caratteristiche fisico-chimiche di mieli del Friuli Orientale. Industrie Alimentari, v. 22, n. 210, p. 849-58, 1983.

SPORNS, P.; PLHAK, L.; FRIEDRICH, J. Alberta honey composition. Food Research International, v. 25, n. 2, p. 93-100. 1992.

STEFANINI, R. Variability and analysis of Italian honeys. Apiacta, v. 19, n. 4, p.109-114. 1984. 
STONOGA, V. I.; FREITAS, R. J. S. de. Conteúdo de água e açúcares em mel de abelha B. CEPPA, v. 9, n. 1, p. 13-16, 1991.

TABIO, C.; ALVAREZ, J.D.; BERISIARTU, M. Preliminary characterization of some physico-chemical and organoleptic characteristics of Citrus honeys from Jaguey Grande, Matanzas. Ciencia y Tecnica en la Agricultura, Apicultura, v. 3, p.29-39, 1987.

TEMIZ, A. I. Composition and characteristics of honeys from the Izmir region, and effects of different storage methods. Ege Bolge Zirai Arastirma Enstitusu Yayinlari, v. 31, n. 11, p.113, 1983. /Resumo em CAB Abstracts on CD-ROM, 1984-86.

THRASYVOULOU, A. The use of HMF and diastase as criteria of quality of Greek honey Journal of Apicultural Research, v. 25, n. 3, p. 186-95, 1986.

THRASYVOULOU, A. MANIKIS, J.; TSELIOS, D. Liquefying crystallized honey with ultrasonic waves. Apidologie, v. 25, n. 3, p.297-302, 1994.

THRASYVOULOU, A.; MANIKIS, J. Some physiochemical and microscopic characteristics of Greek unifloral honeys. Apidologie, v. 26, p. 441-452, 1995.

TREVISAN,, M. D. P.; TREVISAN, M.; VIDAL, R. Os produtos das abelhas. SNAP, STA-SEP; FUNDAÇÃO EDUCACIONAL DE BARRETOS. p.24, 1981. 
UÑATES, M. A.; AGUILAR, A. B. PIOLA, H. D. et al. Estudio físico-químico de mieles de la provincia de San Luis-República Argentina. Archivos Latinoamericanos de Nutricion, v. 49, n. 2, p. 193-196, 1999.

VANSELL, G. H.; FREEBORN, S. B. Preliminary report on the investigations of the source of diastase in honey. Journal of Economic Entomology. v. 22, p.922-926, 1929.

VERÍSSIMO, M. T. da L. Saiba o que é o HMF. Apicultura no Brasil, v. 4, $n$. 24: 31p., 1988.

VIDAL, R.; FREGOSI, E.V. de. Mel: características, análises físico-químicas, adulterações e transformações. Barretos: Instituto Tecnológico Científico "Roberto Rios", 1984. 95p.

VIT, P. Physical-chemical characteristics of commercial honeys from Venezuela. In: AUSTRALIAN AND INTERNATIONAL BEEKEEPING CONGRESS, 2., 1988. Beekeeping in the year 2000. Proceedings. Queensland: International Colour Productions, 1988, p.227-8. Apud Apicultural Abstracts, v.42, n.2, p.168, 1991 (Resumo).

VIT, P.; MARTORELLI, I. G. de; PALACIOS, S. L. Clasificación de mieles comerciales venezolanas. Archivos Latinoamericanos de Nutricion, v. 44, n. 1, p. 39-44, 1994.

WHITE JÚNIOR, J. W.; RUDYJ, O. N. The protein content of honey. Journal of Apicultural Research. v. 17 n. 4, p.234-244, 1978.

WHITE JÚNIOR, J.W. Honey. Advances in Food Research. v. 22. p. 287$374,1978$. 
WHITE JÚNIOR, J. W. Methods for determinung carbohydrates, hydroxymetilhyfurfural and proline in honey; Collaborative study. Journal of the Association of Official Analytical Chemists. v. 62, n. 3, p.515-526, 1979.

WHITE JÚNIOR, J. W. Quality evaluation of honey: role of and diasrase assays. American Bee Journal, v.132, n. 12, p.792-794, 1992

WOOTON, M.; RYALL, L. A comparison of Codex Alimentarius Commission and HPLC methods for 5- hidroxy methyl- 2- furaldehyde determination in honey. Journal of Apicultural Research, v. 24, n. 2, p.120-124, 1975. 